\title{
ESTUDO DO EFEITO DE CAMPO ELÉTRICO PULSADO NO REPARO ÓSSEO EM TÍBIA DE RATOS
}

\author{
SABRINA PIVA CALIXTO
}

Dissertação de mestrado apresentada ao Programa de Pós-Graduação Interunidades em Bioengenharia Escola de Engenharia de São Carlos / Faculdade de Medicina de Ribeirão Preto / Instituto de Química de São Carlos da Universidade de São Paulo como parte dos requisitos para a obtenção do título de mestre em Bioengenharia.

Área de concentração: Bioengenharia

ORIENTADOR: Dr. Orivaldo Lopes da Silva

São Carlos

2007 
Ficha catalográfica preparada pela Seção de Tratamento da Informação do Serviço de Biblioteca - EESC/USP

\section{Calixto, Sabrina Piva}

C153e Estudo do efeito de campo elétrico pulsado no reparo ósseo em tíbia de ratos/ Sabrina Piva Calixto. -- São Carlos, 2007.

Dissertação (Mestrado) -- Escola de Engenharia de São Carlos/Instituto de Física de São Carlos/Instituto de Química de São Carlos-Universidade de São Paulo, 2007.

Área: Bioengenharia.

Orientador: Prof. Dr. Orivaldo Lopes da Silva.

1. Campo elétrico. 2. Tecido ósseo. 3. Interagentes físicos e biologicos. I. Título. 
Dedico este trabalho aos meus

Pais, irmãos e esposo pelo apoio e compreensão incondicionais. 


\section{AGRADECIMENTO}

Agradecer é trazer à mente todas pessoas que partilharam um momento único de um desafio composto por instantes de fracasso e madrugadas de vitória. Agradecer é potencializar sua capacidade com os nutrientes do próximo. Agradecer é antes de tudo olhar o caminho da sua conquista e perceber que somente seus passos não serão capazes de percorrê-lo.

Agradecer nesta ocasião é perceber que em cada entrelinha dissertada existe a entrega fiel e a coragem desbravadora de amigos. Agradecer aqui é ser admirada e se apropriar de tal grandeza para escalar os resultados pretendidos.

Agradecer é prostra-se diante do Criador e colocar-se como coadjuvante Dele afim de que seus dons estejam sob minha posse.

Agradecer é saborear esse triunfo de mestre com vocês amigos que me ensinam converter obstáculos em raras preciosidades.

Agradecer, enfim, é reconhecer que precisamos de pessoas para que os nossos projetos se realizem. 


\section{AGRADECIMENTO ESPECIAL}

Agradeço em especial o meu orientador Dr. Orivaldo Lopes da Silva por acreditar em meu potencial e investir horas de paciência, compreensão e sabedoria em minha formação. 


\section{RESUMO}

CALIXTO, S. P. Estudo do efeito de campo elétrico pulsado no reparo ósseo em tíbia de ratos. 2007. 72f. Dissertação (Mestrado) - Escola de Engenharia de São Carlos / Faculdade de Medicina de Ribeirão Preto / Instituto de Química de São Carlos, Universidade de São Paulo, São Carlos, 2007.

O conceito de que estimulação elétrica promove o reparo de fraturas tem uma longa história, datada de 1812. O mecanismo pelo qual estimulação elétrica promove a osteogênese ainda é assunto de especulação científica, entretanto esse método não farmacológico, utilizado no presente trabalho, já mostrou efeitos positivos na promoção e estímulo da osteogênese.O presente trabalho objetivou analisar a influência da aplicação de campo elétrico pulsado nas características histológicas e propriedades mecânicas do tecido ósseo em osteotomias experimentais realizadas em tíbias de ratos. Foram utilizados 52 ratos com fraturas cirúrgicas unilaterais do terço médio da tíbia, sem lesão dos músculos e do periósteo. Os animais foram divididos em dois grupos: grupo controle, que não recebeu estimulação e grupo tratado com campo elétrico. Esses foram divididos em dois subgrupos: animais sacrificados no $19^{\circ}$ pósoperatório e animais sacrificados no $27^{\circ}$ pós-operatório. O membro fraturado foi tratado com campo elétrico pulsado com freqüência fundamental de $1,5 \mathrm{MHz}$ e $200 \mu \mathrm{s}$ de largura de pulso, em sessões diárias de 20 minutos. Realizou-se radiografia desse membro no dia da cirurgia e do sacrifício. Após o tratamento sacrificaram-se os ratos e extraíram-se suas tíbias para a obtenção de material para análise morfométrica e ensaio mecânico de flexão. Os ensaios biomecânicos revelaram que houve diferença significativa entre as médias dos grupos tratado 18 e 12 dias somente para a tensão, sendo esta maior para o grupo tratado 18 dias, para as demais propriedades mecânicas analisadas não houve diferença significativa. A análise morfométrica determinou que a relação entre os grupos controle 18 dias com tratado 18 dias bem como entre os grupos tratado 12 dias e tratado 18 dias das médias das áreas de osso formado apresentaram diferenças estatisticamente significantes. Esses resultados sugerem que existe um incremento na síntese de matriz orgânica no grupo tratado, não acompanhado linearmente pela síntese mineral. A diferença estatisticamente significativa nas tensões de ruptura, por outro lado, sugere que o aumento no grau de mineralização encontra-se em curso.

Palavras-chave: Campo elétrico. Tecido ósseo. Interagentes físicos e biológicos. Biomecânica. 


\section{ABSTRACT}

CALIXTO, S. P. Study of the effect of pulsed electric field on bone healing in rats tibia. 2007. 72f. Dissertation (M.Sc) - Escola de Engenharia de São Carlos / Faculdade de Medicina de Ribeirão Preto / Instituto de Química de São Carlos, Universidade de São Paulo, São Carlos, 2007.

The concept that electrical stimulation promotes the repair of fractures has a long history, dated of 1812. The mechanism for which electrical stimulation promotes osteogenesis is still subject of scientific speculation, however that method nonpharmacological, used in the present work has already showed positive effects in the promotion and incentive of osteogenesis. The present work objectified to analyze the influence of the application of electric field pulsed in the histological characteristic and mechanical properties of the bone tissue in experimental osteotomy accomplished in tibias of rats. 52 rats were used with unilateral surgical fractures of the medium third of the tibia, without lesion of the muscles and of the periosteum. The animals were divided in two groups: group control, that didn't receive stimulation and treated group with electric field. These were divided in two subgroups: animals sacrificed in the 19th after operation and animals sacrificed in the $27^{\text {th }}$ after operation. The fractured member was treated with electric field pulsed with fundamental frequency of $1,5 \mathrm{MHz}$ and $200 \mu \mathrm{s}$ of pulse width, in daily sessions of 20 minutes. The x-ray of that member took place in the day of the surgery and of the sacrifice. After the treatment the rats were sacrificed and their tibias were extracted for the material obtaining for analysis morfométrica and mechanical rehearsal of flexion. The mechanical rehearsals revealed that there was only significant difference among the averages of the treated groups 18 and 12 days for the tension, the treated group 18 days had a larger tension, for the other analyzed mechanical properties there was not significant difference. The averages of the moment of inertia and area went significantly larger for the treated group 18 days when compared with the respective averages of the control group controls. The treated group 12 days presented averages significantly larger when compared to the properties: moment of inertia, neutral line and area with the control group 12 days. These results suggest that an increment exists in the synthesis of organic matrix in the treated group, not accompanied lineally by the mineral synthesis. The difference significant statistic in the rupture tensions, on the other hand, suggests that the increase in the mineralization degree meets in course.

Key Words: Electric field. Bone tissue. Physical and biological interacting. Biomechanics. 


\section{LISTA DE FIGURAS}

Figura 1. Seção de osso que mostra osso cortical e osso trabecular. ..........................18 Figura 2 Detalhe microscópico de osso cortical. (a) esboço 3D de osso cortical, (b) corte de um sistema de Havers, (c) fotomicrografia de um sistema de Havers.

Figura 3 llustração do corpo de prova apoiado em suas duas extremidades e aplicação

de uma força $F$. .32

Figura 4 llustração da Linha Neutra.

Figura 5 Detalhamento da distância do ponto de aplicação da força $F$ ao ponto de apoio. O produto da força $\mathrm{F}$ pela distância origina o momento fletor. 34

Figura 6 Corte com bisturi para expor a tíbia 37

Figura 7 Exposição da tíbia do rato. .37

Figura 8 Realização da osteotomia.

Figura 9 Sutura da pele.

Figura 10 Tratamento com campo elétrico da tíbia osteotomizada. .38

Figura 11 Detalhamento da aplicação da Força F no ensaio mecânico de fexão. 40

Figura 12 Detalhe do osso fixado na placa metálica....

Figura 13 Detalhamento do contorno da sessão transversal do osso.

Figura 14 mostra os menus e a barra de ferramentas do software image ${ }^{\circledR}$ .45

Figura 15 Imagem de uma lâmina com corte histológico longitudinal de uma amostra do grupo controle 12 dias, obtida a partir de um microscópio ótico LeiKA Leitz DMRX, utilizando o software Motic Images Advanced 3.2 de aquisição de imagens.

Figura 16 Representa a área de seleção de tamanho padrão $\left(1 \mathrm{~mm}^{2}\right)$ na região da osteotomia.

Figura 17 Representa o detalhe da seleção de tamanho padrão na região da osteotomia para o cálculo da área

Figura 18 Gráfico da Carga no limite máximo versus Deformação das amostras dos grupos controle e tratado 12 dias.

Figura 19 Gráfico da Carga no limite máximo versus deformação para as amostras dos grupos de 18 dias.

Figura 20 Média da carga no limite máximo. 


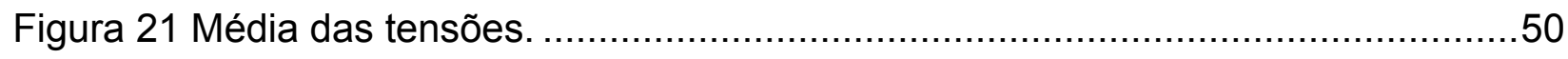

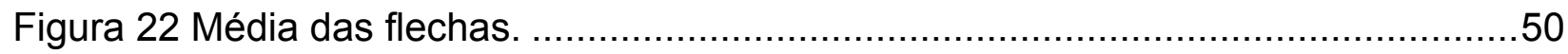

Figura 23 Corte longitudinal de uma amostra da tíbia do grupo controle 12 dias. .........53

Figura 24 Corte longitudinal de uma amostra da tíbia do grupo tratado 12 dias............53

Figura 25 Corte longitudinal de uma amostra da tíbia do grupo controle 18 dias .........53

Figura 26 Corte longitudinal de uma amostra da tíbia do grupo tratado 18 dias ............53

Figura 27 Média da área de osso formado no local da osteotomia para cada grupo .....55 


\section{LISTA DE TABELAS}

Tabela 1. Valores médios e de desvio padrão das propriedades mecânicas das tíbias dos ratos dos grupos controle e tratado.

Tabela 2. Valores médios e desvio padrão das áreas de osso formado no local da osteotomia dos grupos controle e tratado. 


\section{LISTA DE SIGLAS}

Ca - Cálcio

P - Fósforo

Mg - Magnésio

$\mathrm{MPa}$ - Mega Pascal

BMUs - Unidades Básicas Multicelulares

$\mathrm{KHz}$ - Quilohertz

Mm - milímetro

$\mu \mathrm{A}$ - Micro Ampere

PEMF - Pulsed Electromagnetic Field

$\mathrm{mL}-$ Mililitro

$\mathrm{MHz}$ - Megahertz

$\mu s$ - Microssegundo

${ }^{\circ} \mathrm{C}-$ Grau Celsius

$\mathrm{N}-$ Newton

KN - Quilonewton

cm - Centímetro 
SUMÁRIO

RESUMO

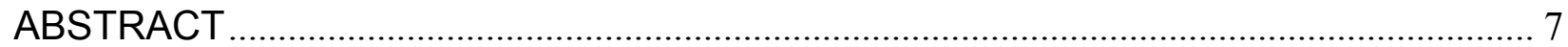

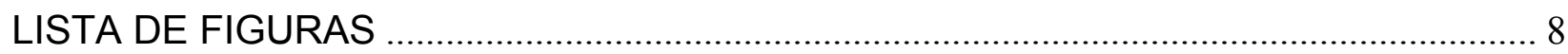

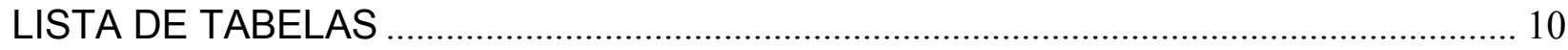

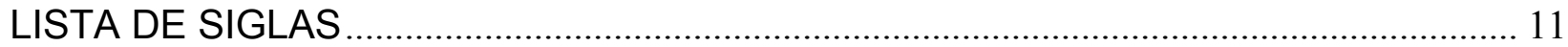

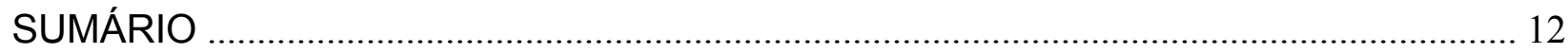

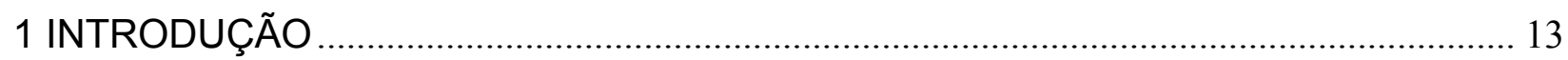

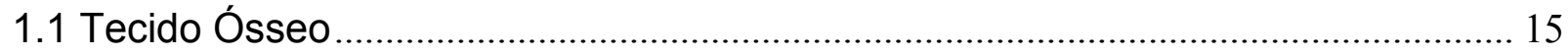

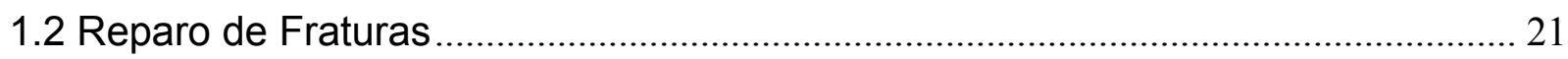

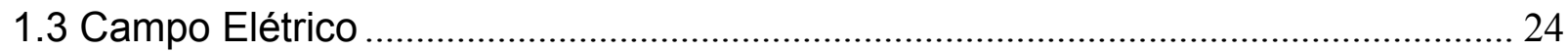

1.4 Propriedades Biomecânicas do Osso....................................................................... 30

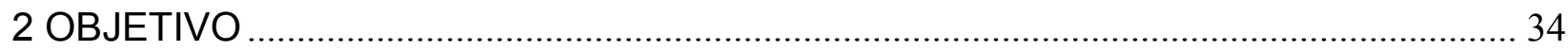

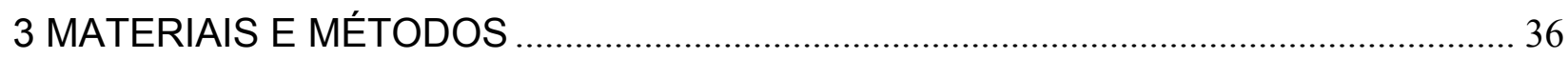

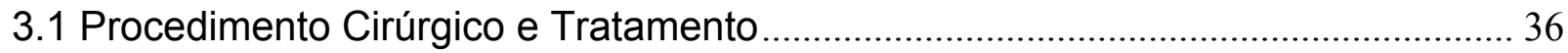

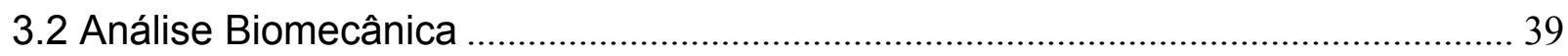

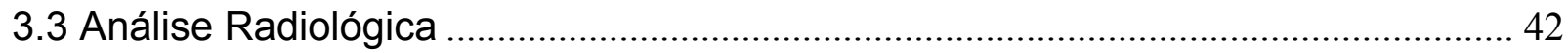

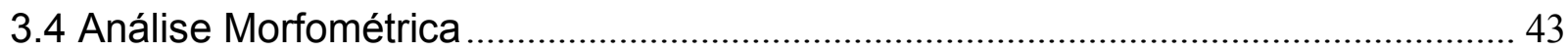

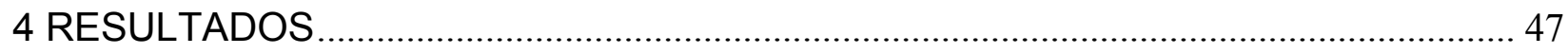

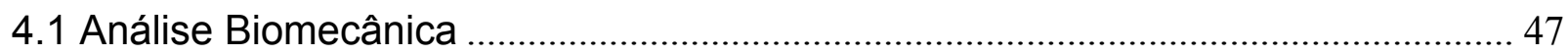

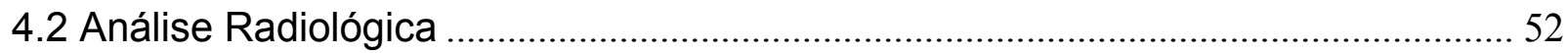

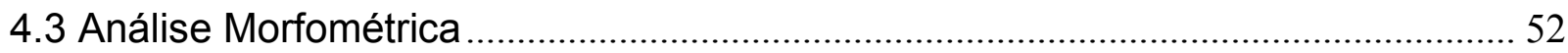

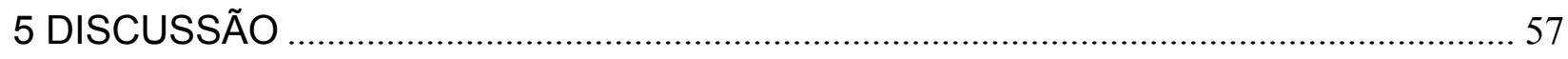

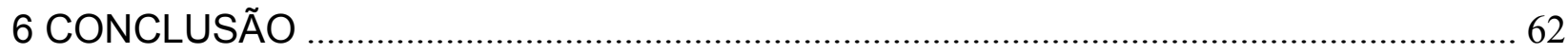

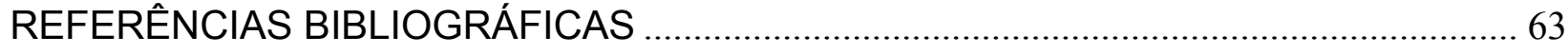

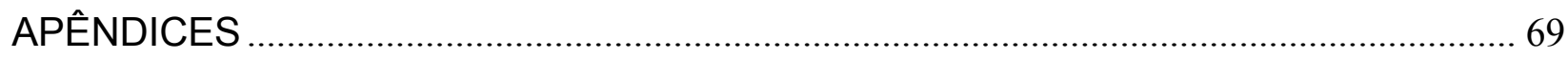




\section{INTRODUÇÃO}

O tecido ósseo tem propriedades estruturais muito interessantes. Isso está essencialmente relacionado à sua composição estrutural: hidroxiapatita, colágeno, quantias pequenas de proteoglicanas, proteínas não colágenas e água (LUCCHINETTI, 2001). Os componentes inorgânicos são principalmente responsáveis pela força de compressão e dureza, enquanto componentes orgânicos provêem as propriedades de tensão. Esta composição varia com a espécie, idade, sexo e incidência ou não de uma doença (GINEBRA; PLANELL e PARICIO, 2000). Outro aspecto importante, que também caracteriza esse comportamento mecânico peculiar, é sua organização hierárquica (WEINER; WAGNER, 1998).

O osso é um material dinâmico que é exposto habitualmente a ambientes mecânicos que desafiam sua integridade estrutural. Há várias causas de fratura óssea, porém, em contraste com materiais inertes, o osso pode regenerar-se formando tecido novo onde foi danificado.

A tíbia é um osso longo, coberta somente por uma fina camada de pele e tecido subcutâneo, sem proteção muscular. Esta localização anatômica pode ser explicada pela necessidade de proteger os vasos sangüíneos e nervos da perna, porém a torna vulnerável a trauma, resultando freqüentemente em fraturas expostas (BYRD et al., 1985).

Fraturas de tíbia são as fraturas de ossos longos mais comuns. As causas mais freqüentes são acidentes de motocicleta ( $28 \%$ dos pacientes), acidentes de veículo (24\%), acidentes domésticos (13\%), acidentes de pedestres $(12 \%)$, lesões por 
esmagamento (8\%), acidentes com arma de fogo $(2 \%)$ e causas diversas como acidente de trabalho esportivo (13\%) (CHANG et al.,1999).

Com a finalidade de acelerar o processo de reparo de uma fratura e também a fim de que a consolidação ocorra com sucesso, pesquisadores não tem medido esforços para elaborar novos métodos de reparo.

O conceito de que estimulação elétrica promove o reparo de fraturas tem uma longa história, datada de 1812, quando corrente elétrica foi usada para consolidar uma fratura. A avaliação dos efeitos promovidos pela estimulação elétrica na consolidação de fraturas ósseas vêm desde o início do século $X X$, baseadas nas propriedades elétricas dos ossos (BRIGHTON, 1985).

Em 1953, quando Yasuda relatou pela primeira vez que era produzida eletricidade quando o osso era deformado artificialmente, efeito denominado "piezoelétrico", propiciou um aumento considerável nas tentativas de encontrar explicações desse efeito na reconstituição óssea. Desde então, têm sido implementados métodos não farmacológicos para minimizar o retardo de consolidação de fraturas. Um exemplo desses métodos é o campo elétrico que aplicado de forma exógena, pode agir como estímulo para o osso.

A maioria dos efeitos biológicos conhecidos de campos elétricos aplicados externamente estão baseados em alterações de potencial elétrico de membrana induzidas por campo elétrico (também chamada de potencial de membrana). Isto pode produzir uma variedade de respostas bioquímicas e fisiológicas profundas em células, tecidos e no corpo como um todo. Quando a célula é exposta a campos elétricos pulsados de alta intensidade, o potencial elétrico suprafisiológico transmembranar é 
induzido, causando a formação de poros na membrana e um aumento na permeabilidade da membrana (BRIGHTON et al., 2001).

Investigações usando culturas de células e também com animais in-vivo apresentaram o campo elétrico como forma de reparar fraturas ósseas sem a necessidade de cirurgia (FRIEDENBERG et al., 1974; LAVINE et al., 1971).

\subsection{Tecido Ósseo}

O esqueleto tem três funções básicas: mecânica, protetora e metabólica. Sustenta o corpo; é o local onde se inserem os músculos; protege os órgãos nobres (vísceras) e a medula óssea; e é o maior reservatório de íons cálcio (Ca), fósforo $(P)$ e magnésio (Mg), necessários para a manutenção da homeostasia mineral (SZEJNFELD, 2000).

O osso é um material composto por duas fases: orgânica e inorgânica. A fase mineral ou inorgânica compreende:

a cerca de $70 \%$ do peso do osso;

a aproximadamente $95 \%$ de cristais específicos de hidroxiapatita, nos quais se impregnam impurezas que constituem os $5 \%$ restantes.

A matriz extracelular ou orgânica do tecido ósseo é constituída principalmente por colágeno ( $98 \%$ de colágeno tipo I), várias proteínas não colágenas e substância fundamental, os 2\% restantes compreende as células (EINHORN, 1994).

De acordo com Robey e Termine (1992), o colágeno compreende aproximadamente $90 \%$ do total de proteínas ósseas presentes na matriz, constituído de fibras colágenas feitas quase exclusivamente de colágeno tipo I. O colágeno tipo I é a 
forma mais abundante de colágeno presente no corpo, amplamente distribuído no tecido conjuntivo.

Existem mais ou menos 15 tipos de colágeno conhecidos. É a proteína mais estudada pois é a mais bem distribuída em mamíferos. São longas cadeias de glicina e prolina que formam uma rígida fita tripla helicoidal. O colágeno formador de fibrilas é o do tipo I, que associado ao do tipo $\mathrm{V}$ forma pele, ossos, tendões, ligamentos etc. $\mathrm{O}$ colágeno do tipo II forma a cartilagem hialina e a elástica e o colágeno do tipo III forma as fibras reticulares. Os colágenos associados a fibrilas são os do tipo IX e XII, que fazem a ligação entre fibrilas e entre outros componentes da matriz. Existem ainda os colágenos formadores de redes, como o do tipo IV e o do tipo VII.

As fibras colágenas do osso são insolúveis e extremamente estáveis. Resultam de várias ligações covalentes intra e intermoleculares. A estrutura primária do colágeno tipo I é composta por seqüências de três aminoácios: glicina-X-Y, onde $X$ e $Y$, freqüentemente, são os aminoácidos prolina e hidroxiprolina respectivamente. A repetição dessa seqüência permite a formação de polipeptídeos com três colágenos, denominados cadeias $\alpha$, que formam moléculas helicoidais tríplices (HULMES, 1992).

O colágeno tipo I é um heteropolímero composto por duas cadeias $\alpha_{1}$ e uma $\alpha_{2}$. As fibras colágenas estão orientadas de modo unidirecional e alternam-se de camada a camada. Em condições normais, essa orientação resulta em um padrão típico de lamelas paralelas mais bem visualizadas com luz polarizada ou microscópio eletrônico.

Os fatores de crescimento ósseo consistem em menos de 1\% das proteínas não colágenas (LIND, 1998), são produzidos pelos osteoblastos e incorporados na matriz extracelular durante a formação óssea, mas pequenas quantidades podem ser removidas do soro e incorporadas à matriz. Os fatores de crescimento estão localizados 
dentro da matriz até que a remodelação ou o trauma causem sua solubilização e liberação (URIST, 1994; LIND, 1998).

Esta composição varia com a espécie, idade, sexo, o tipo de osso e se ele foi ou não afetado por uma doença (GINEBRA; PLANELL e PARICIO, 2000).

Há dois tipos de ossos: cortical (compacto) e trabecular (esponjoso). Aproximadamente $80 \%$ da massa óssea esquelética é constituída por osso cortical, e 20\%, por esponjoso, que ocupa a maior superfície.

O osso cortical é formado por camadas densas calcificadas, constitui as corticais dos ossos longos, também encontrado na camada externa de todos os ossos e é o principal componente do esqueleto apendicular (periférico). Sua função primária é a sustentação e a proteção do esqueleto.

O osso trabecular está presente nos ossos do esqueleto axial e nas epífises dos ossos longos, ele ocupa o espaço interno entre as corticais dos ossos e é constituído por uma rede de barras ósseas horizontais e verticais chamadas de trabéculas, dispostas como uma colméia (GLIMCHER, 1976).

Existe uma diferença estrutural entre o osso trabecular e o cortical: 80 a $90 \%$ do osso compacto é calcificado, contra apenas 15 a $25 \%$ do osso trabecular, os demais 75 a $85 \%$ do osso trabecular são ocupados por medula óssea, vasos sangüíneos e tecido conectivo (SZEJNFELD, 2000).

A diferença funcional entre ambos os tipos de ossos está relacionada à sua estrutura, onde o osso cortical tem função basicamente mecânica e de proteção, enquanto que o osso trabecular tem principalmente função metabólica. Em situações de solicitação de força, o osso trabecular suporta melhor as forças compressivas e o osso cortical as forças torcionais e encurvamento (ALBERTS, 1989). 


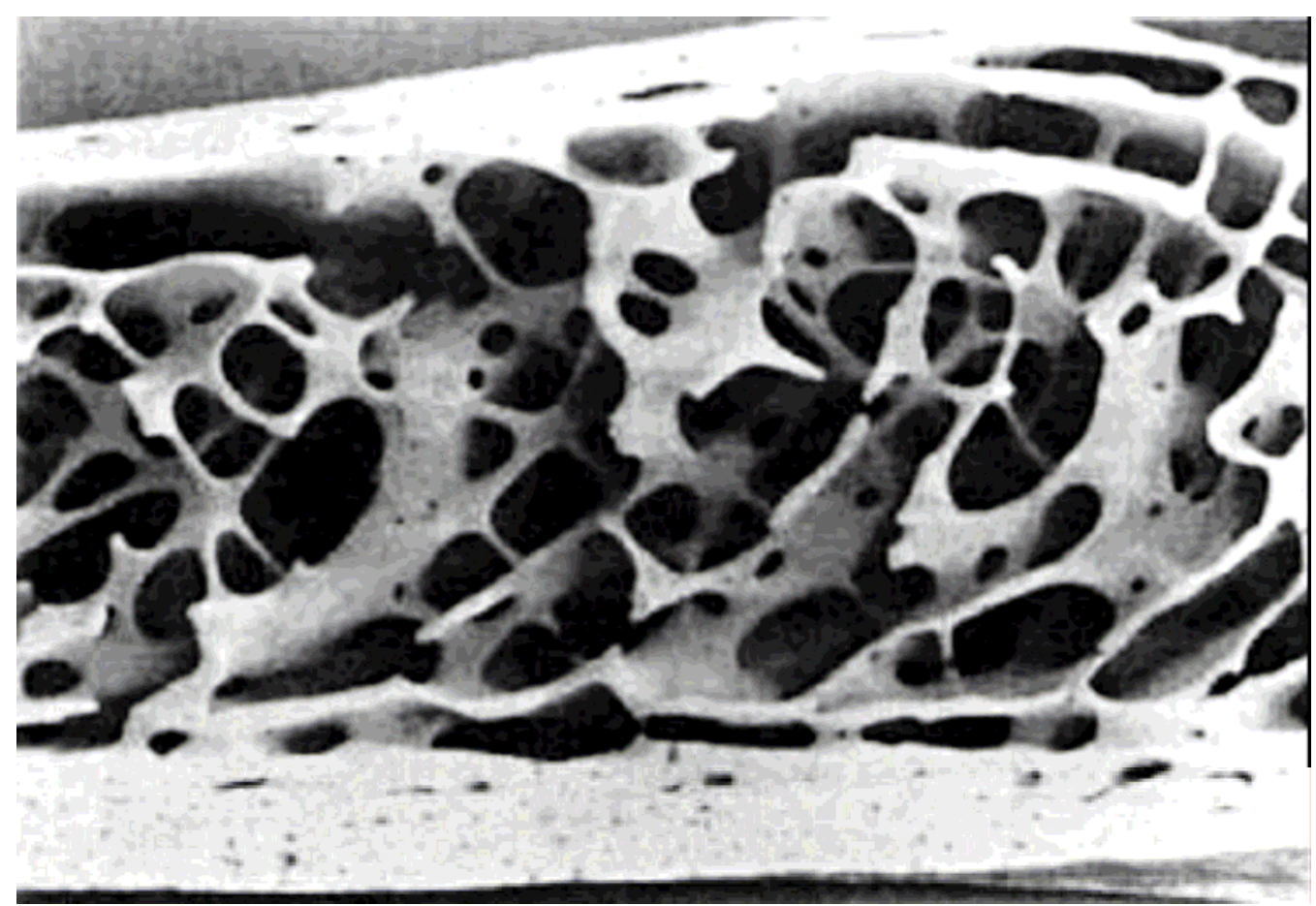

Figura 1. Seção de osso que mostra osso cortical e osso trabecular. FONTE: Doblaré; García e Gómez, (2004)

Em sua constituição o osso apresenta o Sistema Havers que é o arranjo estrutural básico localizado no osso compacto. Esse sistema consiste de um canal de Havers que por sua vez contém nervos, vascularização sangüínea, lamelas que são anéis concêntricos da matriz e canalículos que provêem um vínculo entre os osteócitos ${ }^{1}$.

\footnotetext{
${ }^{1}$ Clopton Havers, médico britânico e anatomista, 1650-1702
} 


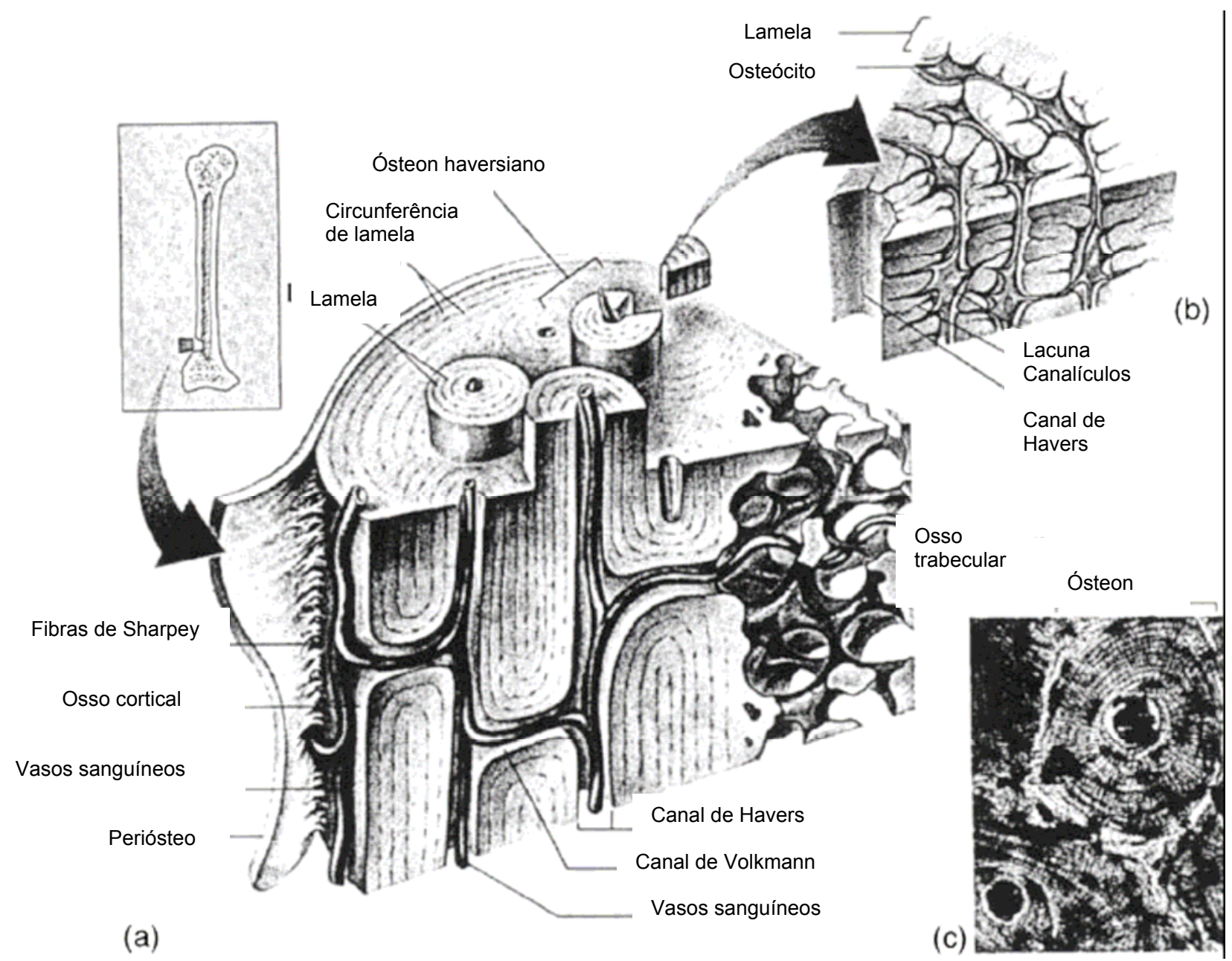

Figura 2 Detalhe microscópico de osso cortical. (a) esboço 3D de osso cortical, (b) corte de um sistema de Havers, (c) fotomicrografia de um sistema de Havers.

FONTE: Doblaré; García e Gómez (2004)

O osso é um tecido conjuntivo muito especializado e que, devido à intensa atividade celular, se desenvolve por meio de um processo chamado ossificação, osteogênese ou simplesmente, formação óssea. As células que constituem a matriz óssea são os osteócitos que se situam em cavidades ou lacunas no interior da matriz, os osteoblastos são as células responsáveis pela síntese da matriz e os osteoclastos, 
células gigantes multinucleadas, estão relacionadas com o processo de remodelação óssea.

Durante a formação óssea as células osteoblásticas sintetizam um material orgânico inicialmente amorfo, que logo em seguida torna-se densamente fibroso chamado osteóide. Os cristais de hidroxiapatita de cálcio são então depositados no osteóide, que se transforma na matriz óssea propriamente dita. Os osteoblastos ficam aprisionados nessa matriz onde diferenciam-se em osteócitos, desse modo, precursores dos cristais de hidroxiapatita de cálcio difundem-se nas fibras colágenas e no cimento e o osteóide converte-se em osso.

O osso também passa por um processo chamado de reabsorção, onde células gigantes e multinucleadas chamadas osteoclastos aparecem nas áreas submetidas à erosão, conhecidas por lacunas de Howship.

O osso também é anisotrópico. O osso cortical tem uma porosidade muito pequena e sua anisotropia é principalmente controlada pelas orientações de lamelas e ósteons. O contrário acontece com o osso trabecular que tem uma porosidade maior e sua anisotropia é determinada através da orientação trabecular. É difícil quantificar anisotropia experimentalmente, recentemente têm sido propostas várias medidas de distribuição direcional de massa óssea do osso trabecular. Cowin (1986) definiu anisotropia do osso por meio do denominado tensor de tecido, que define os valores e direções principais da distribuição de massa óssea.

Anisotropia estrutural tem influência direta nas propriedades de rigidez como também nas propriedades de força. Como exemplo, temos que a força comum de um osso humano compacto em Reilly e Burstein (1975) era $105 \mathrm{MPa}$ em um teste de compressão longitudinal e $131 \mathrm{MPa}$ em um teste de compressão transversal. A média 
da força longitudinal em tensão na mesma experiência era $53 \mathrm{MPa}$ (REILLY; BURSTEIN, 1975 ).

A bioeletricidade é uma das respostas não-hormonais mais estudadas no osso. Potenciais elétricos gerados por estresse podem ser verificados, o que denomina-se piezoeletricidade. Essencialmente, esses fenômenos representam a conversão direta da energia mecânica em energia elétrica, utilizando o osso como meio. A função celular gera efeitos bioelétricos independentes do estresse. A capacidade do osso agir como um tecido que se desenvolve, produz e transmite sinais elétricos depende das funções de suas células, matriz e fase mineral. A influência que esses potenciais fisiológicos exercem sobre a remodelação óssea não está ainda bem definida (EINHORN, 1994).

\subsection{Reparo de Fraturas}

O remodelamento de uma fratura é um processo extremamente complexo no corpo humano. Em condições adequadas, o osso fraturado pode ser reconstituído, quase que identicamente, à sua forma original. Ao longo de muitos anos, desenvolveram-se extensas investigações sobre esse processo de remodelamento ósseo.

O remodelamento de uma fratura pode acontecer de dois modos: remodelação primária ou direta e a remodelação secundária ou indireta (FROST, 1989; EINHORN, 1998).

A remodelação primária de fraturas envolve uma tentativa direta do córtex para restabelecer a interrupção. O osso em um lado do córtex tem que se unir com o osso no outro lado do córtex a fim de restabelecer a continuidade mecânica. Este processo parece acontecer somente nos casos de extrema estabilidade, desconsiderando-se a 
amplitude da interrupção entre os fragmentos, havendo a tentativa do osso de se formar diretamente (EINHORN, 1998). A remodelação secundária de fraturas envolve os estágios clássicos de remodelamento, isto é, inflamação, formação do calo, mineralização e remodelação (MCKIBBIN, 1978; IWAKI et al., 1997; SANDBERG et al., 1993).

$\mathrm{Na}$ ocorrência de um impacto, quando o osso absorve energia além de sua tenacidade, uma fratura acontece ao longo da linha de menor resistência. O impacto fere a medula óssea local, o periósteo, os tecidos moles adjacentes e rompem-se os vasos sangüíneos. Primeiramente, a fratura sensibiliza as células locais e as capacita a responder melhor a mensagens e estímulos sistêmicos, em seguida, lança mensageiros bioquímicos e biofísicos a fim de que as células possam responder. Esta sensibilização biológica dura por volta de 7 dias (FROST, 1989; EINHORN, 1998).

$\mathrm{Na}$ fase de inflamação, ocorre a formação de hematoma e a hemorragia é o resultado do rompimento do periósteo e dos vasos sangüíneos no local da fratura. As extremidades dos vasos sangüíneos sofrem trombose e são lançadas enzimas, nesse momento o pH torna-se ácido. Macrófagos, leucócitos e outras células inflamatórias invadem a área (EINHORN, 1998) e clinicamente, esta fase é associada a dor, inchaço e aquecimento (CRENSHAW, 1992).

$\mathrm{Na}$ fase de formação do calo transitório, as células são estimuladas a iniciar a produção de novos vasos sangüíneos, fibroblastos, material intracelular e células de apoio, que formam tecido de granulação no espaço entre os fragmentos de fratura. Depois disso, macrófagos e outras células surgem a fim de remover o tecido morto (EINHORN, 1998). Esta fase dura aproximadamente duas semanas (FROST, 1989) e 
clinicamente corresponde ao tempo em que a união clínica é estabelecida através de tecido fibroso ou cartilaginoso (CRENSHAW, 1992).

O estágio de mineralização do calo transitório começa aproximadamente 1 semana após a formação de calo suave novo. O aumento de oxigênio conduz à produção de osteóide que consiste, principalmente, em hidroxiapatita de cálcio opaco que o faz radiológicamente visível. A presença de osteóide provê rigidez dentro do calo.

A quantidade de formação de calo depende da estabilidade relativa dos fragmentos da fratura. No local da fratura onde há mais movimento torna-se necessária a formação de um calo maior para preveni-lo (EINHORN, 1998). Quando o local da fratura adquiriu estabilidade e força, o paciente pode retomar a atividade limitada. A formação e mineralização do calo podem durar cerca de 4 a 16 semanas, podendo ser um processo mais rápido em crianças e em osso esponjoso (CRENSHAW, 1992).

Os osteoclastos agem na remodelação da superfície externa do osso diminuindo o tamanho do calo. A vascularização local, oxigenação e pH tornam-se normalizados, então a cartilagem mineralizada é substituída inicialmente por osso tipo esponjoso que em seguida também é substituído por osso lamelar. O calo formado na extremidade do osso compacto é substituído por ósteons secundários, compostos de osso lamelar. Estes ósteons alinham-se paralelamente às linhas de compressão e tensão causadas pelo estímulo mecânico e força muscular. A completa substituição do calo por meio da remodelação óssea dura cerca de quatro anos (FROST, 1989).

O tecido ósseo é renovado constantemente por meio de um processo denominado remodelamento ósseo que não é executado individualmente por cada célula, mas por grupos de células que funcionam como unidades organizadas, que Frost (1963) nomeou "Unidades Básicas Multicelulares" (BMUs). Eles operam no 
periósteo, no endósteo, na superfície trabecular e no osso cortical, substituindo osso velho por osso novo em discretos pacotes. Os BMUs sempre seguem uma sucessão bem definida de processos, normalmente conhecida como a sucessão A-R-F (ativaçãoreabsorção-formação).

Muitos estudos experimentais (HSIEH et al., 2002; VERBOGT et al., 2000; MUIR, 1999; BENTOLILA, 1998) e teóricos (SCHAFLLER; JEPSEN, 2000; LEE et al., 2000; MARTIN, 2002; HAZELWOOD et al., 2001) têm sugerido que o tecido ósseo possa reparar micro danos através do remodelamento. Alguns autores consideram que a acumulação de micro danificações é o incentivo mecânico para a remodelação.(MARTIN, 1995; RAMTANI; ZIDI, 2001).

\subsection{Campo Elétrico}

A utilização da corrente elétrica para estimular o tecido ósseo durante o processo de consolidação e formação de calo ósseo tem sido reportada por vários autores.

O desenvolvimento da tecnologia elétrica permitiu estudos das propriedades elétricas dos tecidos biológicos. A. d'Arsonval foi o primeiro, em 1892, a conduzir experimentos utilizando correntes elétricas de alta freqüência, geradas por um sistema constituído por 2 jarros de Leyden e uma bobina de núcleo de ar. Seguiu-se N. Tesla, que utilizou correntes alternadas no intervalo entre 10 e $100 \mathrm{KHz}$. Estes pesquisadores obtiveram achados notáveis para a época, entre eles o fato de correntes elétricas de alta freqüência não produzirem choque e contrações musculares, atravessando o corpo com pequeno efeito, o que surpreendeu os fisiologistas contemporâneos. Tesla, em 
1898, propôs que os tecidos biológicos seriam "condensadores", ou seja, ofereceriam baixa resistência para altas freqüências (FOSTER; SCHWAN, 1989).

No século XX (década de 70), multiplicaram-se os esforços para a aplicação da eletricidade na estimulação da osteogênese. Em 1976, já era possível a análise de uma diversidade de técnicas para osteogênese eletricamente estimulada (MARINO, 1977). Foram utilizadas correntes contínuas variáveis (ANDREWS; FRIEDENBERG, 1970), correntes pulsadas (LEVY, 1974) e correntes pulsadas com formas de onda semelhante àquelas desenvolvidas no osso por deformação (TREHARNE et al., 1979). Ainda foram utilizados estímulos através da aplicação de eletretos em contato com o osso in vivo (YASUDA, 1977) e de campos eletromagnéticos (BASSETT; PAWLUK e PILLA et al, 1974).

Têm sido especulados por muitos anos tratamentos com aplicação de campo elétrico. As identidades dos mecanismos celulares que são influenciados por ele e facilitam os efeitos positivos, permanecem desconhecidas. Muitos estudos in vitro (BRIGHTON et al, 2001; KORENSTEIN et al., 1984 ) e relatórios in vivo (FRIEDENBERG et al.,1971) revelam que os efeitos benéficos podem ser atribuídos à ativação de proteínas de membrana, e especificamente proteínas que envolvem mecanismos de transdução de sinal. Não somente as proteínas podem ser afetadas, mas também é estabelecido agora que há aumento da afluência de $\mathrm{Ca}^{2+}$, observada após a excitação elétrica de células. O tratamento de fraturas com campo elétrico também contribui a muitos processos celulares cálcio-dependentes que podem ser unidos aos efeitos terapêuticos. Estes efeitos incluem o alívio de dor, diminuição da inflamação, ferida e reparo da fratura óssea e aumento da circulação sanguínea 
(ULETT; HAN E HAN, S., 1998; SLUKA et al., 1999; ZIZIC et al., 1995; BRIGHTON et al., 1998).

Num estudo de caso realizado em 2004 pelo Center for Health Policy and Center for Primary Care and Outcomes Research, Stanford University, onde foi remetido um questionamento a 346 médicos diretores de planos de saúde se o critério especificado na política de cobertura desses planos incluiria a estimulação elétrica de crescimento ósseo e se eles cobririam esta intervenção para um paciente hipotético com união anormal de fratura de osso longo. Entre os dados levantados nesta pesquisa está que $228(66 \%)$ dos 346 diretores indicados responderam que aproximadamente $72 \%$ dos planos têm uma política de cobertura formal para estimulação elétrica de crescimento ósseo no caso de fraturas de osso longo, mais que $30 \%$ dos planos especificam que devem transcorrer 4 meses ou mais antes que se aplique a estimulação elétrica, embora estudos clínicos não sustentem em absoluto esta espera. Diretores de aproximadamente $61 \%$ dos planos com política que requer estender os períodos de espera, todavia, autorizariam estimulação elétrica para pacientes que não se encontram neste critério (HUANG et al., 2004).

Brighton et al. (1995), publicaram uma análise retrospectiva usando um modelo de regressão logística para comparar a eficácia relativa de acoplamento capacitivo, corrente direta e enxerto ósseo no tratamento de não união de tíbia. A análise comparou as taxas de reparo, os fatores de risco identificados e predisse a probabilidade de sucesso desses três métodos de tratamento em 271 não uniões de tíbia, com um tempo médio de 23,5 meses após a fratura. O primeiro resultado mostrou que a taxa de remodelamento para não união de tíbia sem fatores de risco foi equivalente entre corrente direta, acoplamento capacitivo de campos elétricos e enxerto 
ósseo. Entre os fatores de risco identificados estavam o tempo da fratura, o tipo da fratura e o fracasso anterior de excitação elétrica ou cirurgia de enxerto ósseo. Em fraturas de 70 meses ou mais, como houve um aumento no número de fatores de risco, uma significante baixa na estatística da eficácia foi observada. O principal achado desta análise foi o retratamento com o mesmo método que mostrou diminuições estatísticas significantes no reparo. Por exemplo, se uma fratura tinha sido previamente tratada sem sucesso com cirurgia de enxerto ósseo, um tratamento subseqüente com o mesmo procedimento resultou em sucesso diminuído. Um achado adicional importante foi que não uniões atróficas eram mais resistentes para excitação elétrica que não uniões hipertróficas. Este foi o primeiro relatório que usou regressão logística para se dirigir este complicador em um estudo clínico com dispositivos elétrico e eletromagnético.

Pereda Cardoso et al. (1996), estimularam o tecido ósseo por meio de corrente elétrica bipolar de 20 microamperes e menos de 1 volt com uma freqüência de $1 \mathrm{~Hz}$, associada à fixação externa do osso, utilizando 29 pacientes com diferentes lesões ósseas. Demonstraram o papel coadjuvante da eletricidade na consolidação óssea, sendo que ao analisar os resultados, encontraram um tempo médio de 12 semanas para a consolidação de pseudoartrose da tíbia que é muito inferior ao do grupo não tratado, resultando num tempo médio de 34 semanas.

Ainda, Yonemori et al. (1996), num estudo utilizando coelhos que depois de serem submetidos a uma intervenção cirúrgica que expôs o úmero onde foi perfurada uma cavidade de $1,0 \mathrm{~mm}$ de diâmetro, demonstrou-se que com a inserção de fios Kirschner nessa cavidade, oferecendo uma corrente contínua de $10 \mu \mathrm{A}$ continuamente durante 14 dias, a atividade da fosfatase alcalina na medula óssea aumentou após 7 
dias da cirurgia. Depois de 14 dias da cirurgia, a atividade da fosfatase alcalina e a atividade proliferativa dos osteoblastos foram significativamente mais altas quando comparadas aos grupos controle e estimulação com campo eletromagnético pulsado. A formação de novas células ósseas foi mais ativa no grupo de estimulação com corrente contínua. Concluiu-se que a estimulação elétrica é eficaz na promoção da osteogênese, quando na região estimulada existam células sensíveis a esse tipo de estímulo. Os resultados desse estudo poderiam justificar a causa do estímulo elétrico ser eficaz em alguns casos e em outros não.

Estudos demonstram que a estimulação elétrica altera a incorporação de íons de cálcio nas células. O transporte de cálcio acoplado a atividade da ATPase é essencial para o crescimento e reparo ósseo. Berg e Zhang (1993) relataram que a estimulação elétrica eleva o potencial de membrana da célula, o que resulta na elevação de sua condutividade, afetando assim, as funções de suas proteínas e lipídeos.

Skerry, Pead e Lanyon (1991) demonstraram a inibição de perda óssea com campos eletromagnéticos pulsados em um modelo canino ovariectomizado e concluíram que este efeito era atribuível à inibição de reabsorção na superfície óssea e não a excitação de formação de osso novo.

Brighton et al. (2001), estudaram os caminhos bioquímicos que são ativados na transdução de sinal quando vários tipos de estimulação elétrica são aplicados nas células ósseas, determinando o DNA contido em cada placa. Todos sinais produziram um aumento significante de DNA por placa comparados com os grupos controle em todos os períodos de tempo, mas somente a exposição por acoplamento capacitivo resultou em um aumento significativo na produção de DNA em cada período de tempo, além de trinta minutos. Concluiu-se que os eventos iniciais em transdução de sinal 
apresentaram resultados diferentes quando acoplamento capacitivo foi comparado com os outros meios de estimulação (acoplamento indutivo e campos eletromagnéticos), o evento inicial com pares de capacitores é a afluência de íons de $\mathrm{Ca}^{2+}$ através de portões de voltagem da membrana celular por canais de cálcio, enquanto que o evento inicial das demais estimulações é a incorporação de $\mathrm{Ca}^{2+}$ para armazenamento intracelular.

Também foram investigados os efeitos da aplicação de um campo eletromagnético pulsado (PEMF) em fase recente de reparo ósseo num modelo de osteotomia em tíbia canina. Foi executada uma osteotomia transversal (buraco de 2 $\mathrm{mm}$ ) unilateral em doze cachorros adultos de raça não definida e estabilizada com fixação externa. Seis animais foram tratados diariamente com PEMF durante $1 \mathrm{~h}$. A estimulação teve início 4 semanas depois da cirurgia e teve duração de 8 semanas. Nenhuma estimulação foi aplicada ao grupo controle $(n=6)$. A aplicação de carga no grupo de PEMF a 8 semanas foi maior que no grupo controle. A área de calo do periósteo teve um aumento 6 semanas seguintes à cirurgia no grupo PEMF, enquanto um aumento significante foi observado de 8 e 10 semanas depois da cirurgia no grupo de controle. O torque máximo normalizado e torsional de rigidez do grupo PEMF foi significativamente maior que do grupo controle. Análises histomorfométricas revelaram maior formação de osso novo no tecido local da osteotomia, aumento na taxa de justaposição mineral e diminuição da porosidade no córtex adjacente à linha da osteotomia no grupo de PEMF. Concluiu-se que estimulação PEMF de $1 \mathrm{~h}$ por dia durante 8 semanas promoveram recuperação mais rápida de suporte de carga, aumento significante em formação óssea e uma força mecânica mais alta no tecido ósseo neoformado na tíbia osteotomizada (Inoue et al., 2002). 
Apesar de muitos estudos apresentarem o tratamento de correntes elétricas para a estimulação da osteogênese como um método eficaz, vários outros estudos não relataram alterações na osteogênese entre regiões estimuladas e não estimuladas. Spadaro (1997) estudou o efeito de corrente elétrica direta e de campos eletromagnéticos pulsados em implantes de aço inoxidável no canal medular durante três semanas. Os resultados desse estudo demonstraram que se os implantes apresentavam movimentação, a formação de massa óssea ocorria de forma acentuada e em igual proporção, tanto ao ser estimulada eletricamente ou não. Ao estimular com campo eletromagnético, a formação se demonstrou acentuada, enquanto implantes que não possuíam movimentação, recebendo estímulo elétrico ou eletromagnético, apresentaram pouca ou nenhuma resposta osteogênica. Com isso, concluiu-se que a corrente elétrica ou campo eletromagnético são ineficazes para o estímulo da osteogênese quando não associados a alguma forma de estímulo mecânico. Porém, torna-se fundamental lançar a hipótese dessa ocorrência pelo curto período de estimulação para o aumento da massa óssea.

Estudos adicionais devem ser realizados para esclarecer os mecanismos envolvidos quando a aplicação de estímulo elétrico é realizada na busca da promoção da osteogênese.

\subsection{Propriedades Biomecânicas do Osso}

Reparo de fratura óssea é um tópico importante de pesquisa em biomecânica. Durante os últimos anos, muitas teorias e modelos de simulação foram propostos para desenvolver uma visão ampla dos mecanismos que controlam a morfogênese do osso. 
Osso e cartilagem são tecidos mecano-sensívieis e carga mecânica induz deformação espacial e efeitos elétricos associados. Além disso, em situações de aplicação de carga mecânica, potenciais bioelétricos são produzidos por estimular o movimento do fluido intersticial no osso pelo intermédio da matriz extracelular carregada (GRODZINSKY, 1983).

As propriedades biomecânicas do osso podem ser descritas em dois níveis. Primeiro, as propriedades materiais do osso devem ser consideradas e essas propriedades são definidas pelo nível de qualidade do tecido que são independentes da estrutura ou da geometria.

Segundo, as propriedades estruturais do osso, que atuam como uma unidade anatômica. Classicamente, as propriedades materiais dos ossos são definidas por testes mecânicos padronizados. Propriedades estruturais são determinadas em todas seções de osso intactas cuja geometria tenha se mantido.

Quando uma seção uniforme de osso é testada sob condições laboratoriais controladas e as forças aplicadas são conhecidas, quatro propriedades mecânicas básicas do osso podem ser descritas: deformação, capacidade de absorver energia, rigidez e resistência.

No nível baixo de tensão há uma relação linear entre a carga aplicada e a deformação resultante. Essa proporcionalidade é conhecida como módulo de elasticidade e é uma medida de rigidez do osso. A significância fisiológica desta propriedade é o fato de que forças aplicadas no osso em algum ponto ao longo desta linha somente o deformará temporariamente.

Depois que a carga é removida, ele retornará para sua forma original. Quando a região elástica termina a tensão é conhecida como limite elástico. Promover carga além 
deste ponto resultará em uma deformação permanente no material, esta propriedade é conhecida como plasticidade.

A resistência do tecido ósseo é determinada pelo cálculo da máxima carga no ponto onde o osso se rompe. A energia que o osso absorve (energia de deformação) é dissipada quando o osso fratura e é perdida no ponto da falha. A energia armazenada pelo osso até o limite elástico, é conhecida como resiliência. Esta energia é restabelecida se o osso retorna para sua forma original depois que a carga é removida (EINHORN, 1992).

O comportamento mecânico do osso pode ser estudado pela realização de ensaios mecânicos do tecido ósseo, que são importantes, pois fornecem parâmetros fundamentais sobre a resistência dessas estruturas (GOULD III, 1993).

Neste trabalho foi realizado o ensaio de flexão a três pontos, em que o corpo de prova (tíbia) ficou apoiado em suas duas extremidades e sofreu a ação de uma força $F$, que agiu na direção perpendicular ao seu eixo. A figura 1 ilustra a aplicação da força $F$ no corpo de prova.

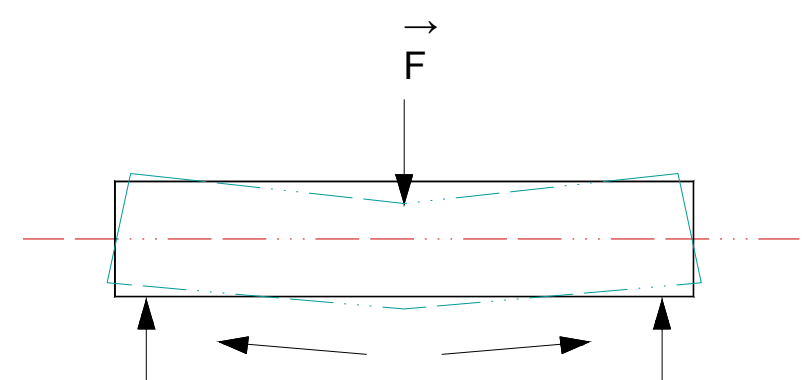

Figura 3 llustração do corpo de prova apoiado em suas duas extremidades e aplicação de uma força $F$.

A força $\mathrm{F}$ leva uma região do corpo a se contrair, devido à compressão, enquanto que outra região se alonga, devido à tração. Entre a região que se contrai e a que se 
alonga fica uma linha que mantém sua dimensão inalterada chamada linha neutra. Em materiais homogêneos, costuma-se considerar que a linha neutra fica igual a distância das superfícies externas inferior e superior do corpo ensaiado.

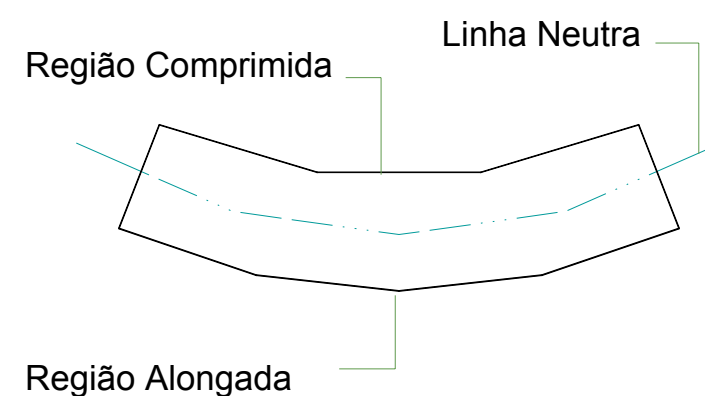

Figura 4 Ilustração da Linha Neutra.

O ensaio de flexão a três pontos permite a avaliação de diversas propriedades biomecânicas do tecido ósseo.

Uma das propriedades biomecânicas dos ossos que podem ser avaliadas por este ensaio é a medida de deformação $(\mathrm{mm})$ chamada de flecha, correspondente à posição de flexão máxima. Nos materiais frágeis, neste caso o osso, as flechas medidas são muito pequenas, conseqüentemente, para determinar a tensão de flexão, utilizamos a carga que provoca a fratura no osso.

Outra propriedade avaliada é o momento fletor, que está relacionado com a distância entre o ponto onde a força $\mathrm{F}$ é aplicada e o ponto de apoio do osso. O produto da força $\mathrm{F}$ pela distância do ponto de sua aplicação resulta no momento, no caso da flexão, é o momento fletor. 

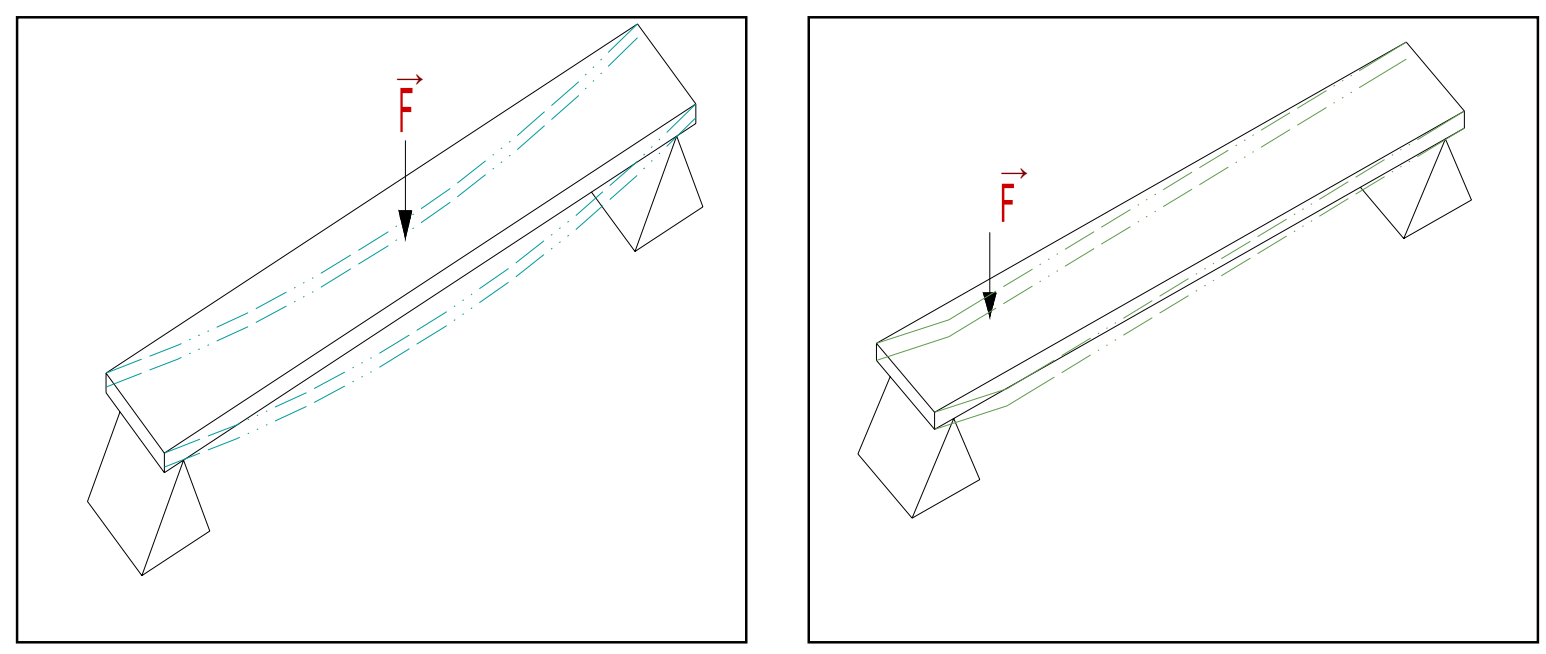

Figura 5 Detalhamento da distância do ponto de aplicação da força $F$ ao ponto de apoio. $O$ produto da força F pela distância origina o momento fletor.

A posição do osso durante o ensaio é um ponto de observação fundamental, pois influencia na sua resistência à flexão, pois cada forma e posição equivalem a um momento de inércia diferente, que é outra propriedade biomecânica avaliada por este ensaio.

A tensão é o resultado de uma força. Quando um material resiste a qualquer tipo de carga externa, desenvolve uma tensão interna. Tensão normal é uma força distribuída que age em uma direção perpendicular para uma determinada área (FRANKEL; BURSTEIN, 1971).

\section{OBJETIVO}

Este trabalho objetivou analisar os efeitos do campo elétrico pulsado no reparo ósseo em tíbia de ratos. Teve objetivo específico analisar a influência da aplicação de 
campo elétrico pulsado nas características histológicas e propriedades mecânicas do tecido ósseo em osteotomias experimentais realizadas em tíbias de ratos. 


\section{MATERIAIS E MÉTODOS}

\subsection{Procedimento Cirúrgico e Tratamento}

Foram utilizados neste experimento 52 ratos da raça Holstman (Rattus norvegicus albinus), fornecidos pelo Biotério Central da UNESP de Araraquara. Eram solicitados ratos machos, adultos jovens e pesavam, em média, $300 \mathrm{~g}$ no dia da cirurgia. Todos os animais foram alojados no Biotério do Laboratório de Bioengenharia da Escola de Engenharia de São Carlos - USP - e tiveram livre acesso à água e ração durante o procedimento experimental.

Para a realização do procedimento cirúrgico o osso selecionado foi a tíbia, por apresentar localização anatômica estratégica, de fácil acesso cirúrgico, já que este trabalho teve por objetivo a realização de uma osteotomia transversal no terço médio da tíbia, onde esta apresenta-se subcutânea.

Os animais foram anestesiados com Ketamim, 0,2 a $0,3 \mathrm{~mL}$ e receberam a mesma dose do relaxante muscular Ronpun. Em seguida, o local da cirurgia foi submetido à tricotomia pré-operatória e com o auxílio de um bisturi o terço médio da tíbia foi exposto sem que causasse lesões no músculo e periósteo, que foram reaproximados posteriormente. Levamos em conta a necessidade de obtermos osteotomias as mais semelhantes possíveis, para que ao realizar o estudo experimental elas fossem passíveis de comparação (GUARNIERO, 1987). Deste modo, todas as fraturas foram realizadas por um único pesquisador. Aceitamos que a não imobilização das osteotomias experimentais das tíbias dos ratos é justificada pela extensão da osteotomia, pois o osso permanece fixado pelo restante da seção transversal intacta do osso. 


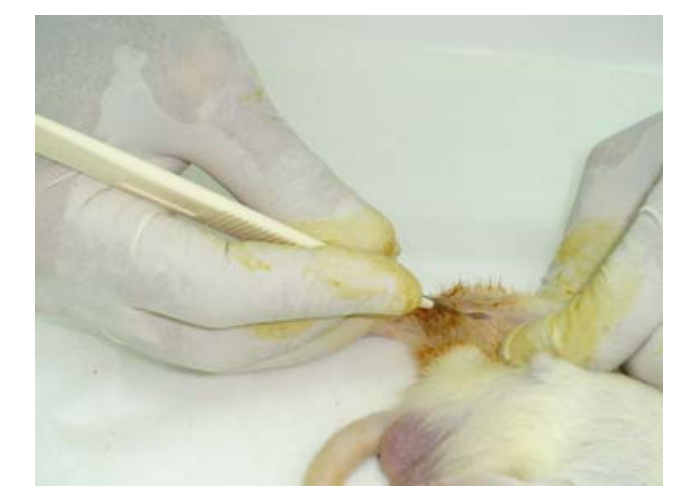

Figura 6 Corte com bisturi para expor a tíbia

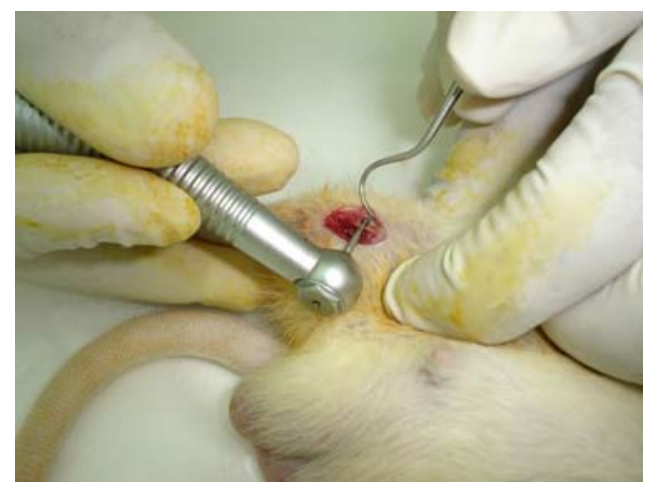

Figura 8 Realização da osteotomia

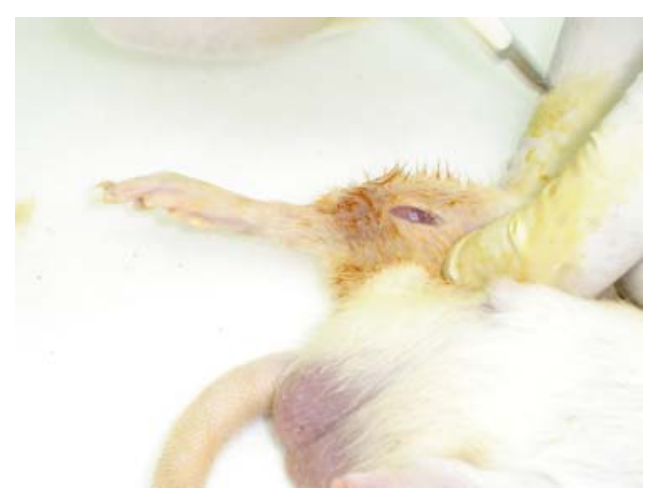

Figura 7 Exposição da tíbia do rato.

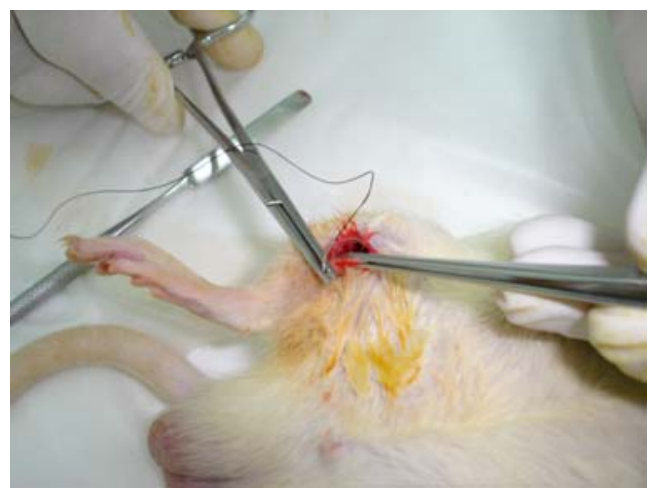

Figura 9 Sutura da pele.

Vinte e seis animais foram divididos em dois grupos de treze animais. No grupo A o membro fraturado foi tratado com campo elétrico variado pulsado com freqüência fundamental de $1,5 \mathrm{MHz}$ e $200 \mu$ s de largura de pulso em sessões diárias de 20 minutos durante 12 dias, com pausas de 2 dias a cada cinco dias de tratamento, iniciando o tratamento no $3^{\circ}$ dia pós operatório e sacrificando-os no $19^{\circ}$ dia pós operatório. $O$ grupo $B$ foi submetido às mesmas condições do grupo $A$, alterando-se apenas o tempo de tratamento de 12 para 18 dias devido ao fato de o estudo das propriedades mecânicas não terem apresentado resultados significativos; essa alteração no período de aplicação do tratamento significa $50 \%$ a mais do que foi aplicado primeiramente. Vinte e seis animais, divididos em dois grupos controle, não 
receberam qualquer tratamento, sendo que foram submetidos à mesma cirurgia e o mesmo protocolo para o sacrifício.

A avaliação radiográfica foi realizada no dia da cirurgia e no dia do sacrifício.
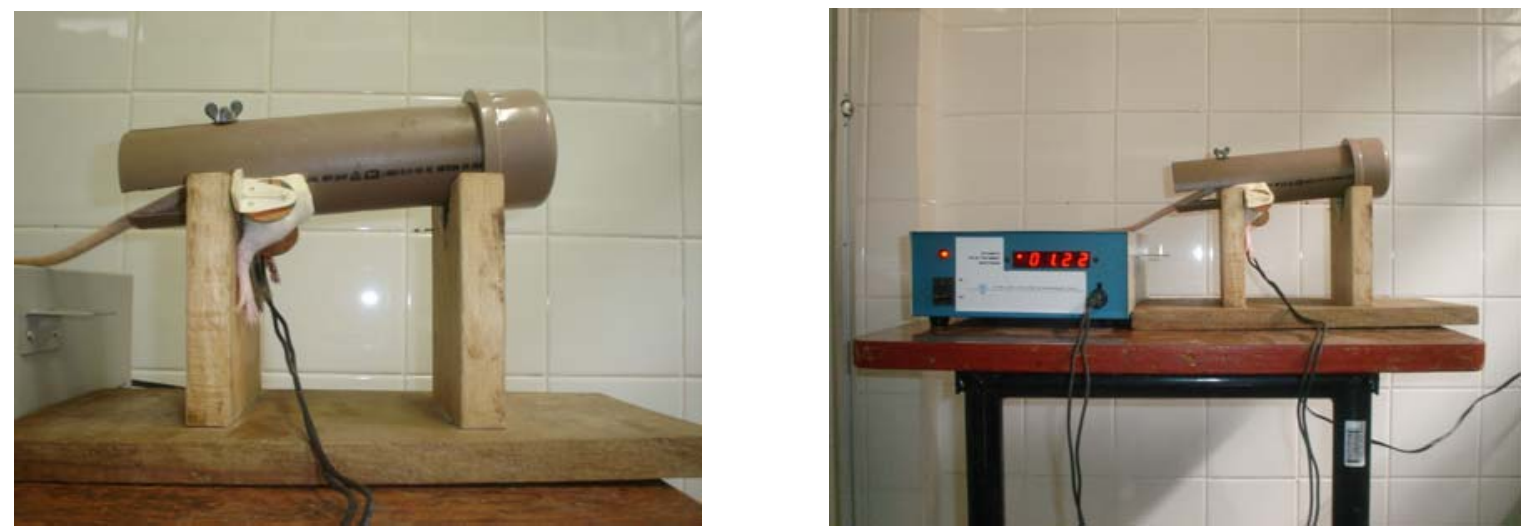

Figura 10 Tratamento com campo elétrico da tíbia osteotomizada.

Após o tratamento os ratos foram sacrificados pelo método de sedação profunda, onde utilizaram-se $0,7 \mathrm{~mL}$ de Ketamin e a mesma quantidade de Ronpun, sem que causasse estresse e suas tíbias foram extraídas, para a obtenção de material para análise histológica e ensaio mecânico de flexão. Três tíbias de cada grupo foram submetidas ao exame histológico que permitiu uma avaliação qualitativa do tecido neoformado. Os ensaios mecânicos de flexão a três pontos submeteram o tecido ósseo neoformado a solicitações de tração, de forma que pudessem ser avaliadas quantitativamente as propriedades mecânicas dos tecidos estimulados e comparadas àquelas do tecido cicatricial obtido naturalmente. Os dados obtidos no ensaio mecânico foram analisados estatisticamente. 


\subsection{Análise Biomecânica}

Após a sedação profunda dos animais, as tíbias foram retiradas por meio de uma incisão longitudinal na região anterior do membro osteotomizado. Em seguida à desarticulação da tíbia, foram retiradas a fíbula e demais estruturas em toda extensão. As amostras foram conservadas em solução salina (solução de cloreto de sódio a 0,9\%) à $-20^{\circ} \mathrm{C}$ em congelador doméstico.

No dia anterior à realização do ensaio mecânico, dez tíbias de cada grupo foram descongeladas em temperatura ambiente.

O ensaio biomecânico de flexão a três pontos foi realizado primeiramente no Laboratório de Neuroendocrinologia no Departamento de Ciências Fisiológicas da Universidade Federal de São Carlos com uma máquina Instron modelo 4444, célula de carga de $1 \mathrm{KN}$ e pré-carga de $5 \mathrm{~N}$ para evitar o deslizamento da tíbia durante o ensaio. Posteriormente realizaram-se os ensaios no Laboratório de Química Analítica e Tecnologia de Polímeros, no Instituto de Química de São Carlos da Universidade de São Paulo com uma máquina Sintex 6.

A Figura 11 representa o detalhamento do osso apoiado em suas extremidades para a aplicação da força $F$. 


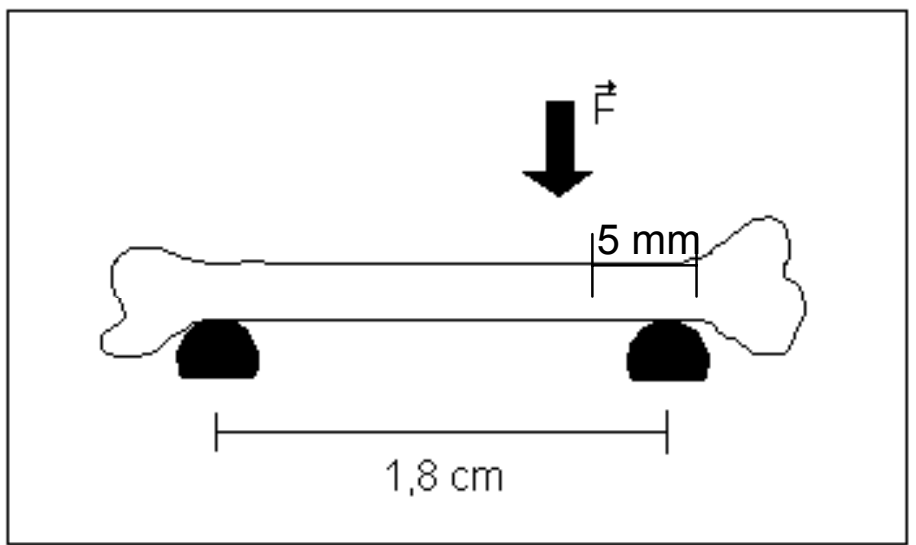

Figura 11 Detalhamento da aplicação da Força F no ensaio mecânico de fexão.

Este ensaio forneceu os valores referentes à carga máxima $(\mathrm{Kn})$ suportada pela tíbia antes de sua ruptura e os valores das flechas que são os deslocamentos (mm) provocados pela carga até o momento da ruptura do osso

Após a realização dos ensaios mecânicos, onde foi promovida uma deformação permanente no osso, as amostras foram cortadas no local da deformação, ou seja, o local onde fora realizada a osteotomia, e fixadas numa placa metálica com massa de modelar de forma que a seção transversal do osso pudesse ser digitalizada. 


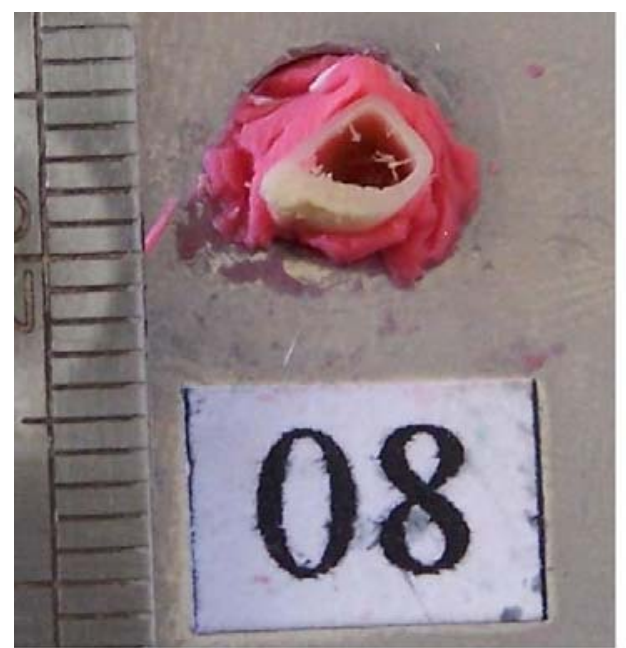

Figura 12 Detalhe do osso fixado na placa metálica

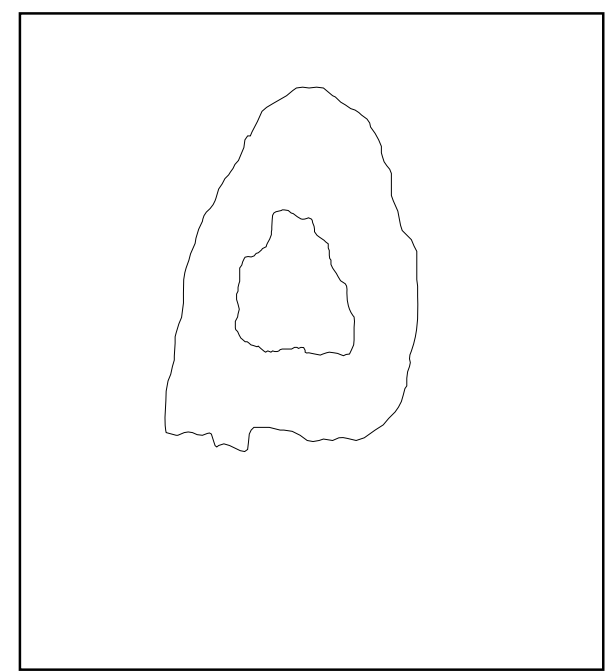

Figura 13 Detalhamento do contorno da sessão transversal do osso.

As propriedades mecânicas área, momento de inércia e linha neutra foram calculadas no programa AutoCAD ${ }^{\circledR}$ da seguinte forma: as sessões transversais das tíbias ensaiadas foram fotografadas com máquina digital ao lado de uma régua com a finalidade de se obter uma escala real e posteriormente as suas imagens inseridas no programa. Em seguida, com o auxílio da ferramenta spline foi realizado o contorno do osso para posterior exclusão da sua imagem, como mostra a figura 13.

Com o auxílio da ferramenta Mass Properties foi possível calcular as propriedades supracitadas.

De acordo com Lirani (2004), o momento fletor M, para a configuração experimental utilizada, é dado por:

$$
M=F .3,61
$$

Onde: $\mathrm{F}$ = carga aplicada (Figura 11) 
A tensão no limite máximo foi calculada pela seguinte equação:

$$
\mathrm{T}=\frac{M . Y}{I}
$$

Onde: $\mathrm{T}$ = tensão no limite máximo de flexão

$$
\begin{aligned}
& M=\text { momento fletor } \\
& Y=\text { linha neutra } \\
& I=\text { momento de inércia }
\end{aligned}
$$

\subsection{Análise Radiológica}

Radiografia é um método tradicional para avaliar o processo de remodelamento de uma fratura, podendo visualizar a formação de calo depois da mineralização (ARONSON; SHEN 1994; KATO et al., 1998; REICHEL et al., 1998). Ela é executada, normalmente, imediatamente após a cirurgia para examinar a localização da fratura ou a qualidade da fixação. Depois do sacrifício dos animais, radiografa-se o local fraturado para que possam ser avaliadas medidas de variedade como densidade de osso ou dimensões do osso. Para fraturas de ossos longos, os parâmetros avaliados são a formação de calo ósseo, a qualidade da união e remodelação do osso (TARVAINEN et al., 1994).

A radiografia do membro osteotomizado foi realizada nos dias da cirurgia e do sacrifício com aparelho de raio-X odontológico, marca Dabi-Atlante, com o objetivo de avaliar e padronizar as osteotomias. 


\subsection{Análise Morfométrica}

A palavra Morfometria é formada pelo radical grego - morphé, que significa a forma, associado ao radical grego - metrikós, ou do latim - metricu, que significa ato de medir ou processo de estabelecer dimensões. Embora o termo tenha aplicação ampla na ciência, o sentido em biomedicina, em última análise seria a "Atividade de medir estruturas anatômicas". Esse método tem por função tornar mais objetiva e precisa a coleta, a apresentação e a análise dos resultados obtidos em pesquisas e na rotina de laboratório, permitindo ainda se relacionar as diferentes estruturas anatômicas com as funções.

As rotinas para a realização da análise morfométrica se iniciaram com a confecção das lâminas no Laboratório de Histologia do Departamento de Bioengenharia de São Carlos da Universidade de São Paulo.

Foram as seguintes rotinas: rotina de coleta, descalcificação, desidratação e diafanização, rotina em parafina histológica, microtomia, diafanização e hidratação, coloração, desidratação e montagem e por fim a rotina de selagem (MICHALANY, 1980).

Após extração das tíbias, iniciou-se a rotina de coleta onde as peças foram lavadas e colocadas em solução fisiológica sob refrigeração, por um período de 24 horas, em seguida, procedeu-se a remoção do tecido muscular e cartilaginoso com o uso de alicates, e as amostras foram cortadas $0,5 \mathrm{~cm}$ antes e após a lesão óssea.

O material foi colocado em Solução de Morse ( Solução I: Citrato de Sódio $20 \%$ e Solução II: Ácido Fórmico 50\%, na proporção 1:1), essa solução foi trocada a cada três dias por um período de 60 dias para a rotina de descalcificação. 
Após as tíbias estarem totalmente descalcificadas, foram lavadas em água corrente por 6 horas, então se deu continuidade ao procedimento com a rotina de desidratação das peças, por meio de banhos em álcoois (Álcool 70\%, Álcool $80 \%$, Álcool 90\%, Álcool 95\%, Álcool Absoluto I e Álcool Absoluto II), em seguida realizou-se a rotina de diafanização das peças por meio dos seguintes banhos: Álcool Absoluto + Xilol , Xilol I e Xilol II, respectivamente.

As peças foram submetidas a dois banhos em parafina, com intervalo de 2 horas cada, sob temperatura de $58^{\circ} \mathrm{C}$ e então emblocadas em parafina e posterior toillete.

As amostras foram cortadas em Micrótomo rotativo com espessura de 0,7 micra, sendo que optamos por corte seriado, elegendo o sétimo corte de cada série de sete. Os cortes foram colocados sobre lâminas histológicas e levados à estufa sob $40^{\circ} \mathrm{C}$, a fim de se obter aderência dos cortes à lâmina de vidro.

Por meio de dois banhos em Xilol a parafina foi removida e seguindo com os banhos em Álcool Absoluto I, Álcool Absoluto II, Álcool 95\%, Álcool 90\%, Álcool 70\% e água destilada, respectivamente, promovemos a hidratação das peças.

Para a realização da coloração, o material foi submetido a banhos seqüenciados em hematoxilina e eosina e posterior lavagem em água deionizada.

Os cortes foram submetidos à rotina de desidratação e montagem através das seguintes seqüências de banhos: Álcool 90\%, Álcool 95\%, Álcool Absoluto I, Álcool Absoluto II, Álcool + Xilol, Xilol I e Xilol II.

Por fim, os cortes eleitos foram selados com lamínula e Entelan.

Posteriormente as imagens das lâminas foram capturadas e digitalizadas com microscópio ótico LeiKA Leitz DMRX, utilizando o software Motic Images Advanced 3.2. Para serem inseridas as escalas das imagens foi utilizado o software Image-Proplus e 
em seguida a área de osso formado em cada corte histológico foi calculada no software image $\mathbb{B}$.

A figura 14 mostra os menus e a barra de ferramentas do software image $J^{\circledR}$ e a figura 15 representa uma imagem obtida a partir de uma lâmina histológica como supracitado.

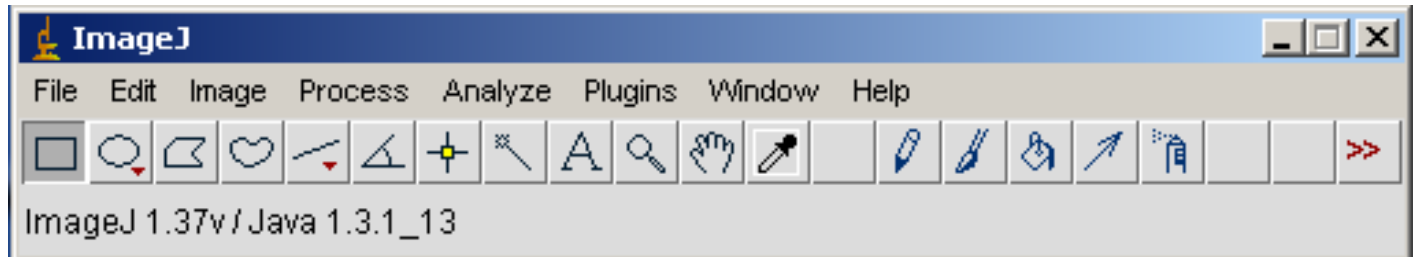

Figura 14 mostra os menus e a barra de ferramentas do software image $\mathrm{J}^{\circledR}$

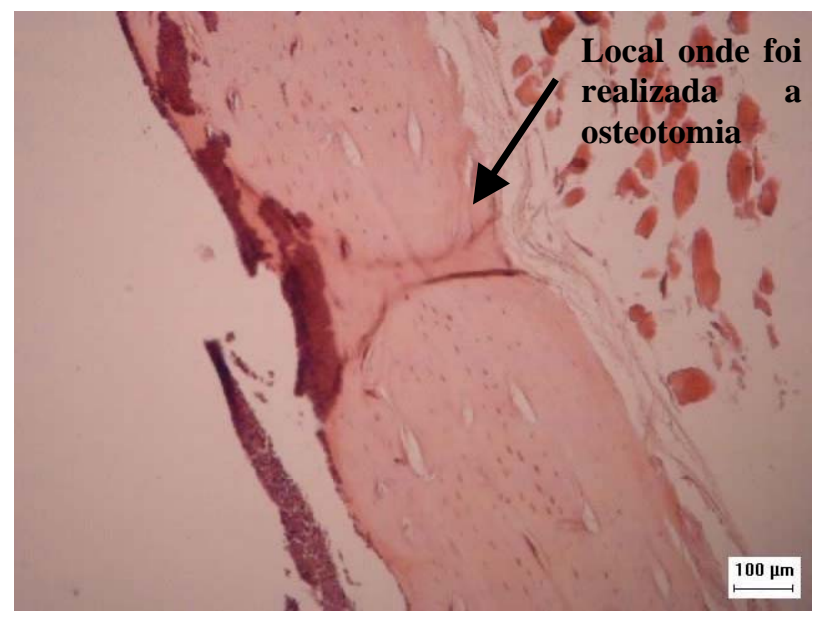

Figura 15 Imagem de uma lâmina com corte histológico longitudinal de uma amostra do grupo controle 12 dias, obtida a partir de um microscópio ótico LeiKA Leitz DMRX, utilizando o software Motic Images Advanced 3.2 de aquisição de imagens. 
Após a aquisição de todas as imagens procederam-se as rotinas para o cálculo da área de osso formado com o programa image ${ }^{\circledR}$.

A fim de se obter um padrão para o cálculo da área de todas as imagens foi criada uma região de interesse em comum, que era uma seleção de tamanho padrão na região da osteotomia. Essa seleção tinha $1 \mathrm{~mm}^{2}$, que foi o tamanho da osteotomia no procedimento cirúrgico, dessa forma o cálculo da área de osso formado foi apenas no local da osteotomia.

Em seguida procedeu-se com a realização do contorno da área de interesse, como representam as figuras a seguir:

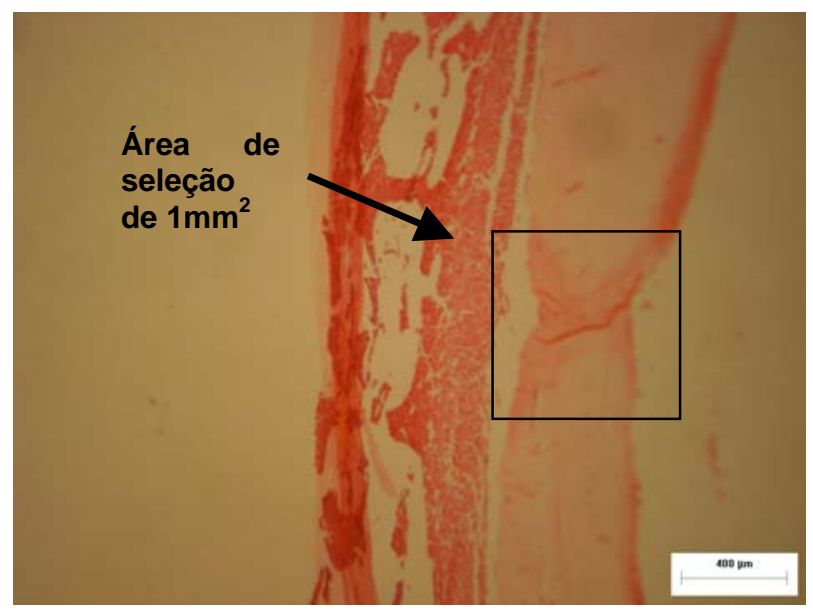

Figura 16 Representa a área de seleção de tamanho padrão $\left(1 \mathrm{~mm}^{2}\right)$ na região da osteotomia.

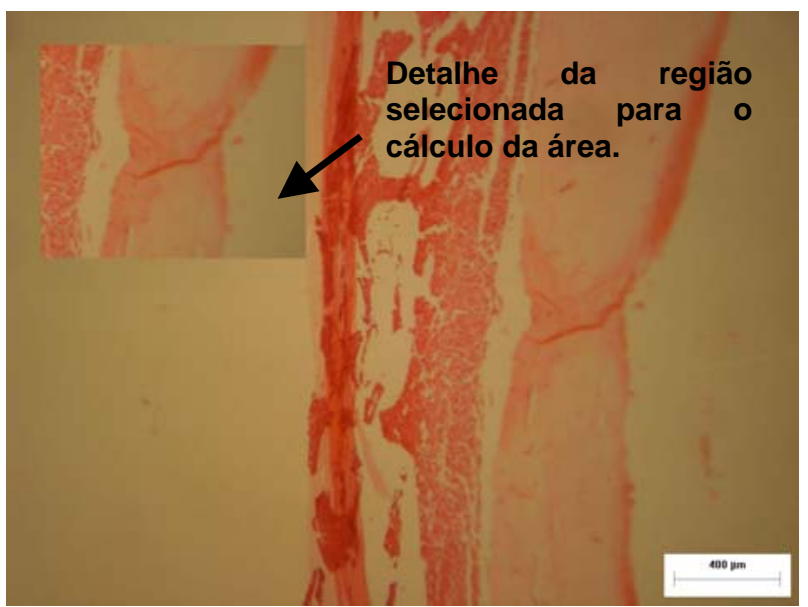

Figura 17 Representa o detalhe da seleção de tamanho padrão na região da osteotomia para o cálculo da área

As áreas de osso formado, ou seja, onde foram realizadas as osteotomias, foram calculadas pelo programa imaje $J^{\circledR}$ para as amostras obtidas de todos os grupos experimentais: grupos controle 12 e 18 dias e grupos tratado 12 e 18 dias. 
Posteriormente os resultados das áreas foram tratados analisados estatisticamente.

\section{RESULTADOS}

\subsection{Análise Biomecânica}

O teste mecânico permitiu a construção de gráficos carga versus deformação das tíbias dos ratos pertencentes aos dois grupos experimentais e controle e, a partir deles, comparar os valores das propriedades mecânicas dos ossos entre os grupos.

As Figuras 18 e 19 representam as médias da carga no limite máximo para cada grupo.

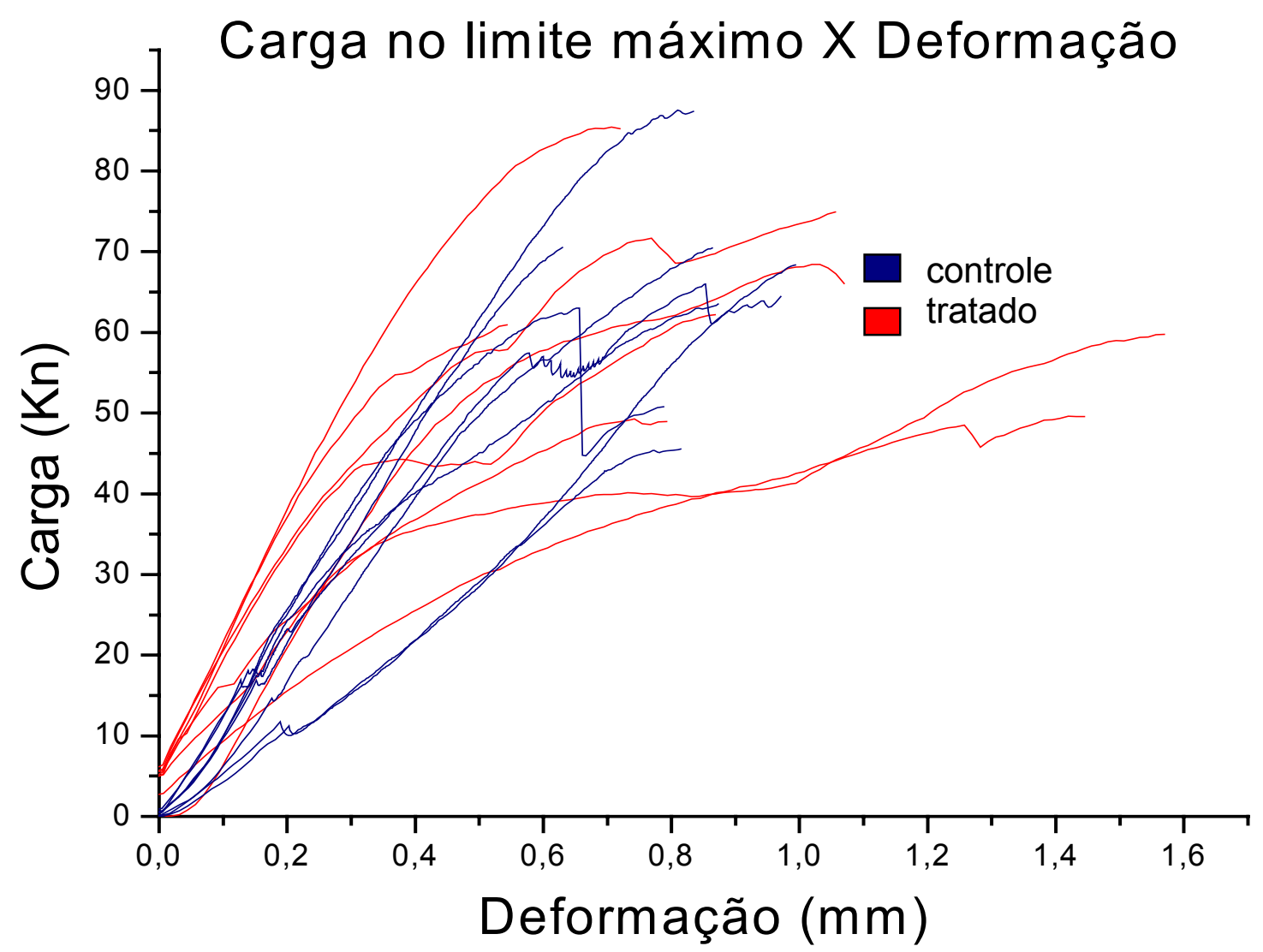

Figura 18 Gráfico da Carga no limite máximo versus Deformação das amostras dos grupos controle e tratado 12 dias 


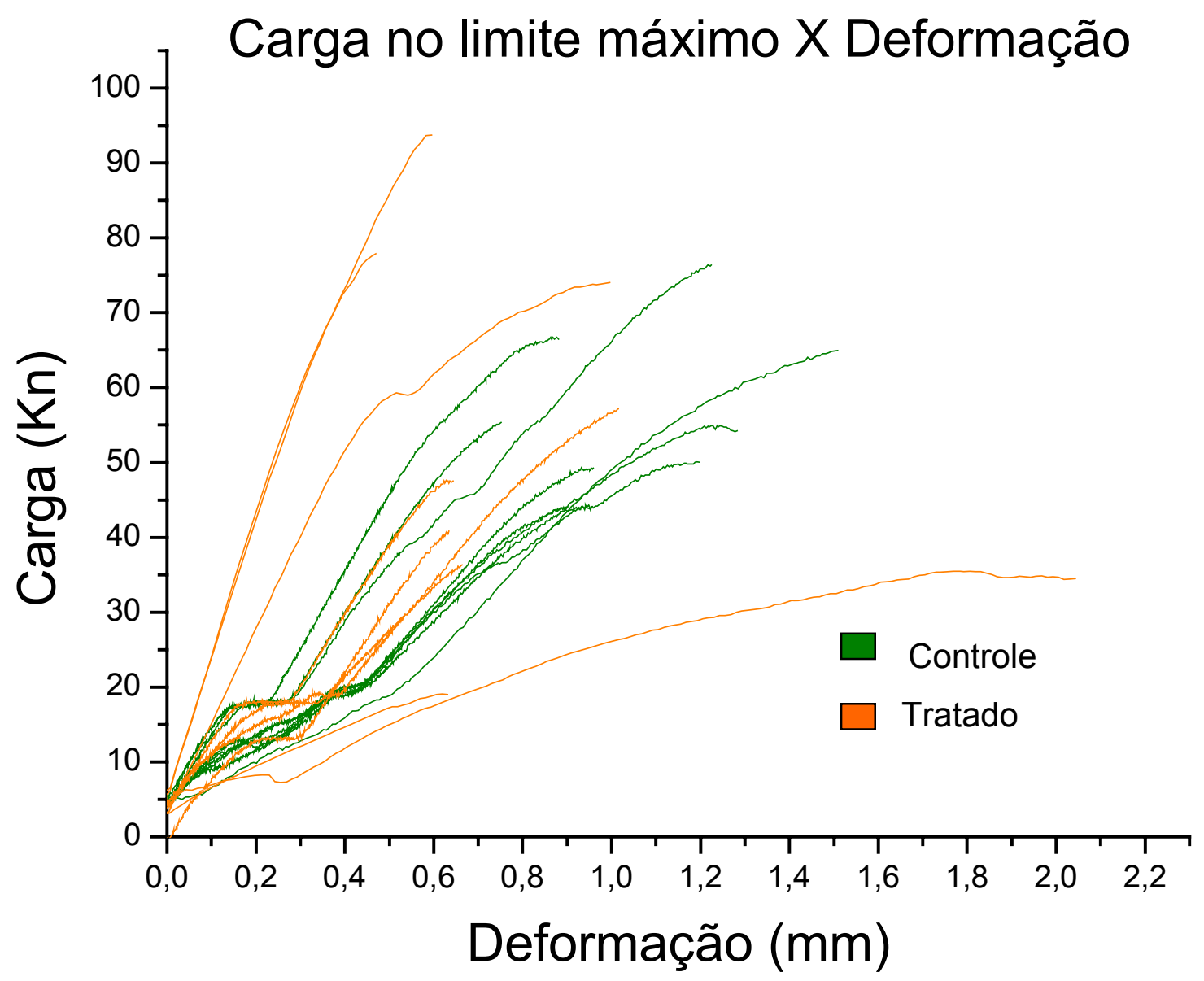

Figura 19 Gráfico da Carga no limite máximo versus deformação para as amostras dos grupos de 18 dias. 
A Figura 20 representa os valores das médias da carga no limite máximo para cada grupo experimental.

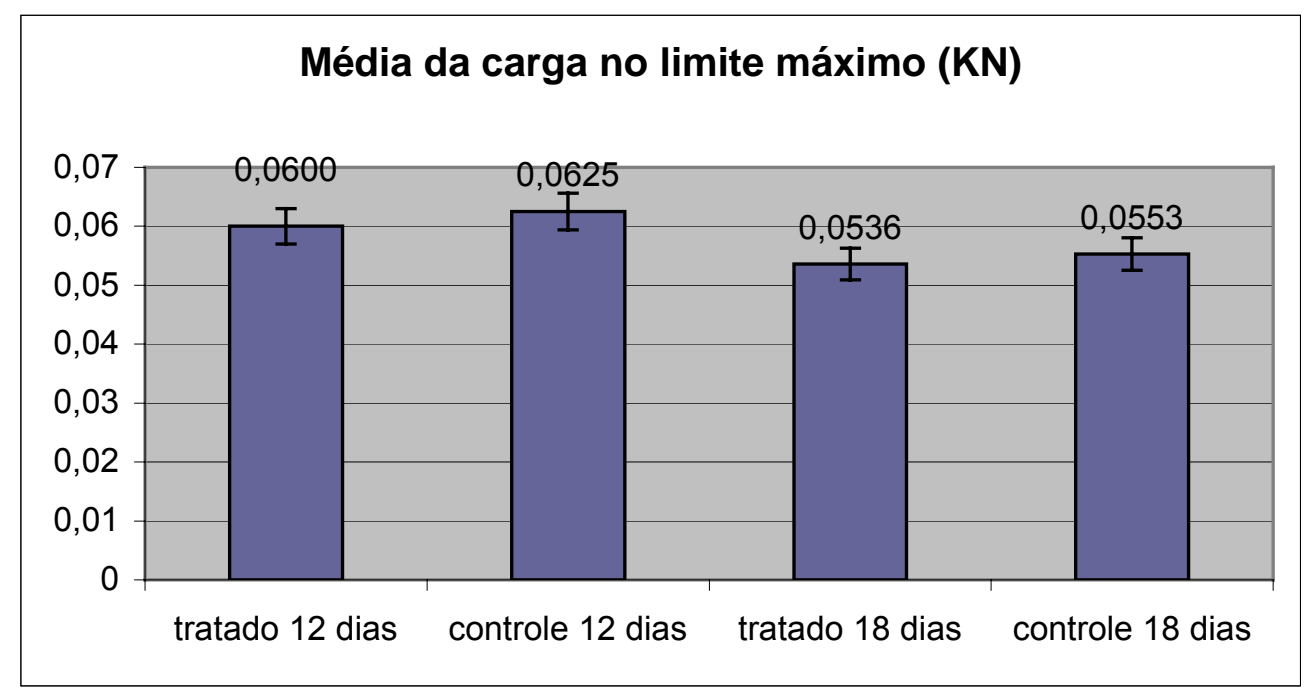

Figura 20 Média da carga no limite máximo.

A análise estatística realizada entre os grupos demonstrou que não houve diferença estatisticamente significante para as médias das cargas no limite máximo suportada pelas amostras dos grupos tratados e controles 12 e 18 dias.

A média das tensões calculada para cada grupo experimental está representada na figura 21 . 


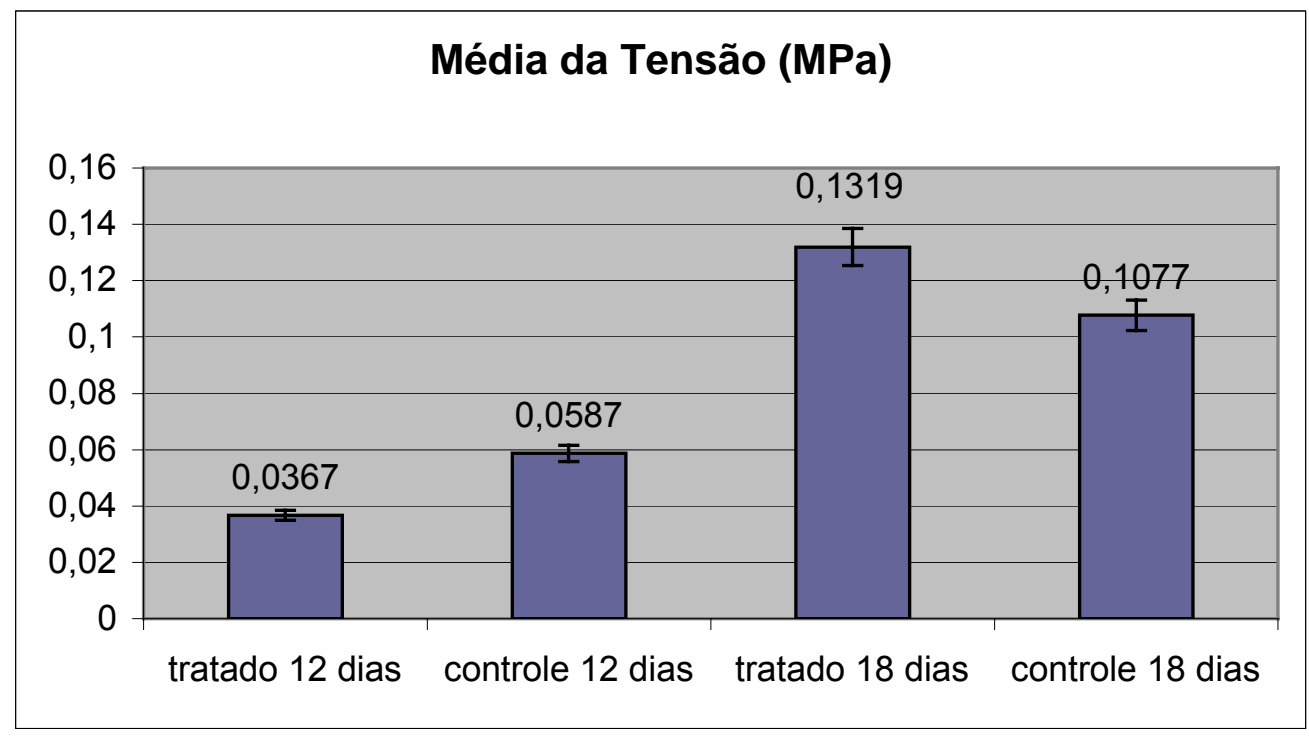

Figura 21 Média das tensões.

O grupo experimental tratado 18 dias obteve diferença estatisticamente significante para a média das tensões quando comparado com o grupo tratado 12 dias.

As médias das deformações suportadas pelas amostras, ou seja, as flechas, estão representadas na figura 22.

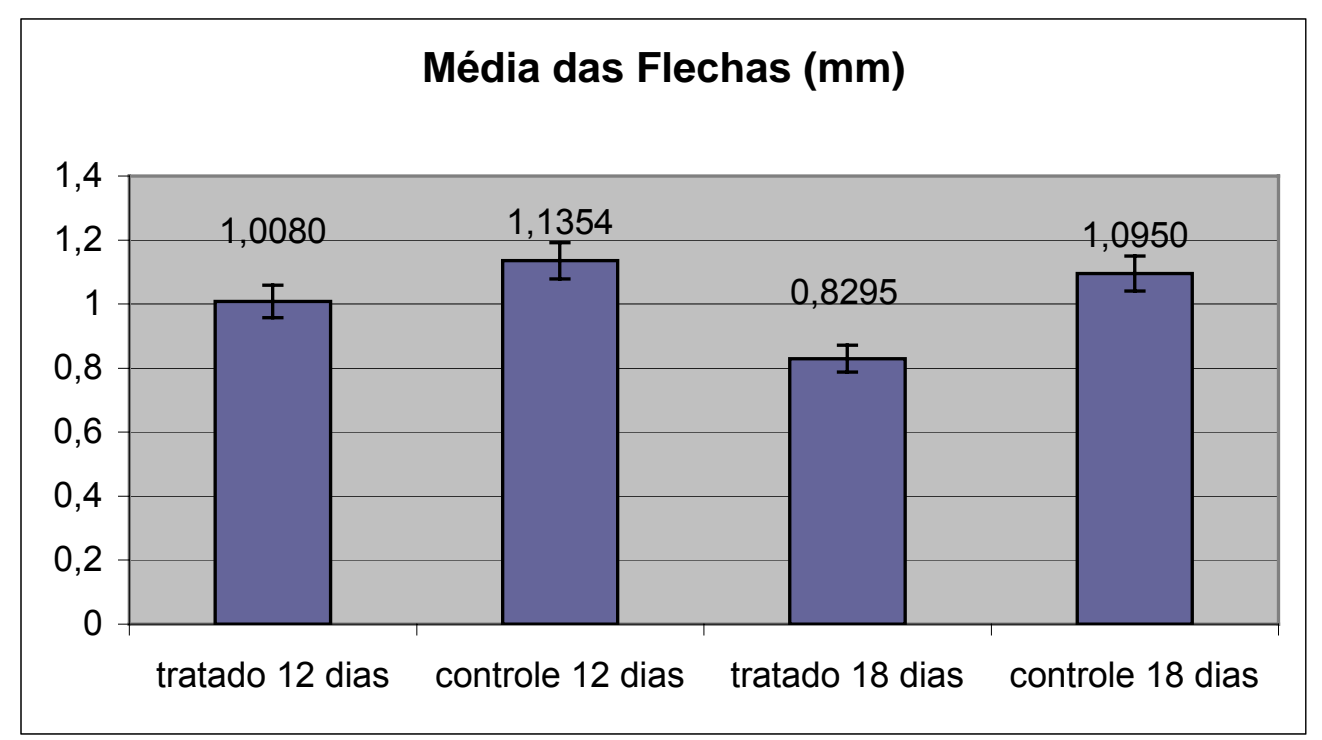

Figura 22 Média das flechas. 
A análise para esta propriedade mecânica demonstrou que não houve diferença estatisticamente significante entre as médias dos grupos experimentais.

A tabela 1 mostra os valores médios e de desvio padrão das diferentes propriedades mecânicas analisadas.

Tabela 1. Valores médios e de desvio padrão das propriedades mecânicas das tíbias dos ratos dos grupos controle e tratado.

\begin{tabular}{llllll}
\hline GRUPO & $\begin{array}{l}\text { M. FLETOR } \\
(\mathrm{N} . \mathrm{MM})\end{array}$ & $\begin{array}{l}\mathrm{M} \text {. INÉRCIA } \\
\left(\mathrm{MM}^{4}\right)\end{array}$ & $\begin{array}{l}\text { TENSÃO } \\
(\mathrm{MPa})\end{array}$ & $\begin{array}{l}\text { ÁREA } \\
\left(\mathrm{MM}^{2}\right)\end{array}$ \\
\hline Controle 12 dias & 8 & $0,2256 ! 0,0379$ & $10,3933 ! 3,3148$ & $0,0587 ! 0,0234$ & $8,1649 ! 1,2817$ \\
Controle 18 dias & 9 & $0,1998 ! 0,0385$ & $6,3612 ! 3,7059$ & $0,1077 ! 0,0336$ & $6,3203 ! 1,4841$ \\
Tratado 12 dias & 6 & $0,2168 ! 0,0493$ & $57,1011 ! 62,0061$ & $0,0367 ! 0,0275$ & $18,9256 ! 14,0131$ \\
& & & & & \\
Tratado 18 dias & 9 & $0,1935 ! 0,0874$ & $18,5968 ! 26,0163$ & $0,1319 ! 0,1031$ & $11,0412 ! 9,5912$ \\
\hline
\end{tabular}

Os resultados não apresentaram diferenças estatisticamente significativas entre as médias calculadas para o momento fletor, quando relacionada essa variável mecânica entre os grupos estudados. O momento de inércia apresentou diferença significativa entre os grupos tratado e controle 12 dias e entre os grupos tratado e controle 18 dias, porém não houve diferença estatística entre as médias dos grupos tratado 18 e 12 dias. O mesmo ocorreu com a análise da diferença das médias das áreas, enquanto observou-se diferença estatística entre as áreas dos grupos tratado e controle 18 dias e tratado e controle 12 dias, não foi observada diferença entre as médias dos grupos tratado 18 e 12 dias. 


\subsection{Análise Radiológica}

A análise radiológica permitiu o acompanhamento das cirurgias, fornecendo a verificação do padrão das osteotomias quanto a localização.

\subsection{Análise Morfométrica}

A análise morfométrica forneceu as áreas de osso formado no local da osteotomia para todos os grupos analisados.

As figuras a seguir ilustram o processo de reparo ósseo ao final do tratamento para cada grupo estudado, nas quais as setas indicam o local onde foi realizada a osteotomia. 


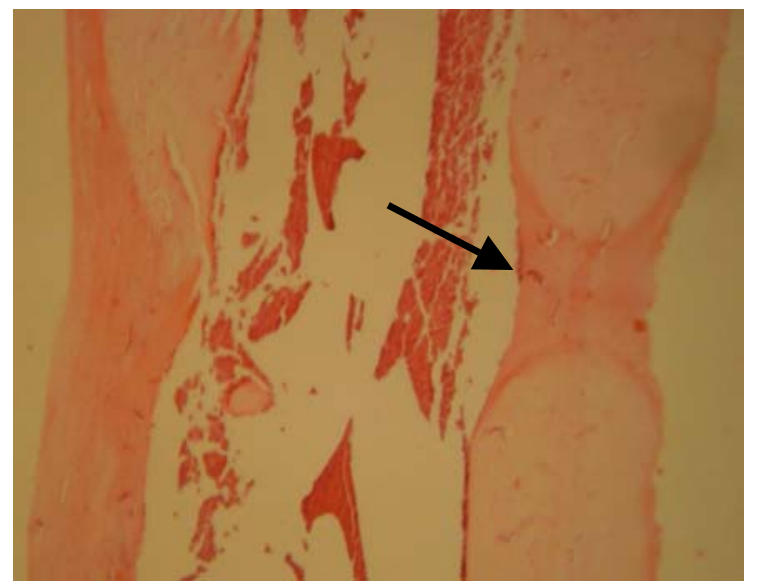

Figura 23 Corte longitudinal de uma amostra da tíbia do grupo controle 12 dias.

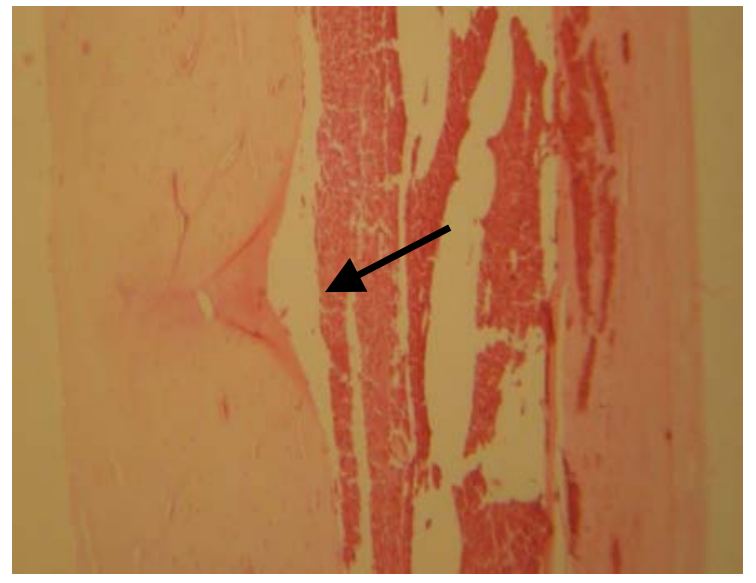

Figura 25 Corte longitudinal de uma amostra da tíbia do grupo controle 18 dias

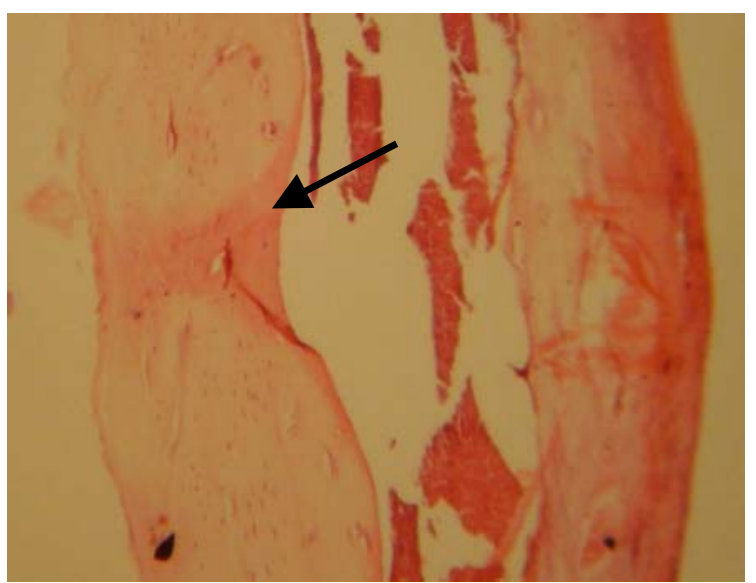

Figura 24 Corte longitudinal de uma amostra da tíbia do grupo tratado 12 dias.

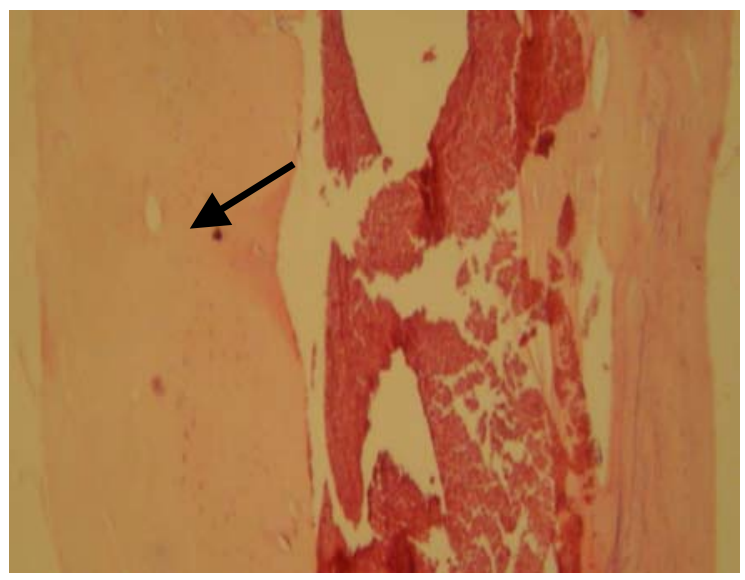

Figura 26 Corte longitudinal de uma amostra da tíbia do grupo tratado 18 dias

As imagens indicam que os grupos de animais sacrificados no $27^{\circ} \mathrm{PO}$ apresentaram maior área de osso formado, bem como os animais tratados com campo 
elétrico pulsado. Pode-se dizer que nas amostras dos grupos tratados observa-se aceleração no processo de regeneração óssea. 
A Figura 27, ilustra as médias das áreas calculadas para cada grupo.

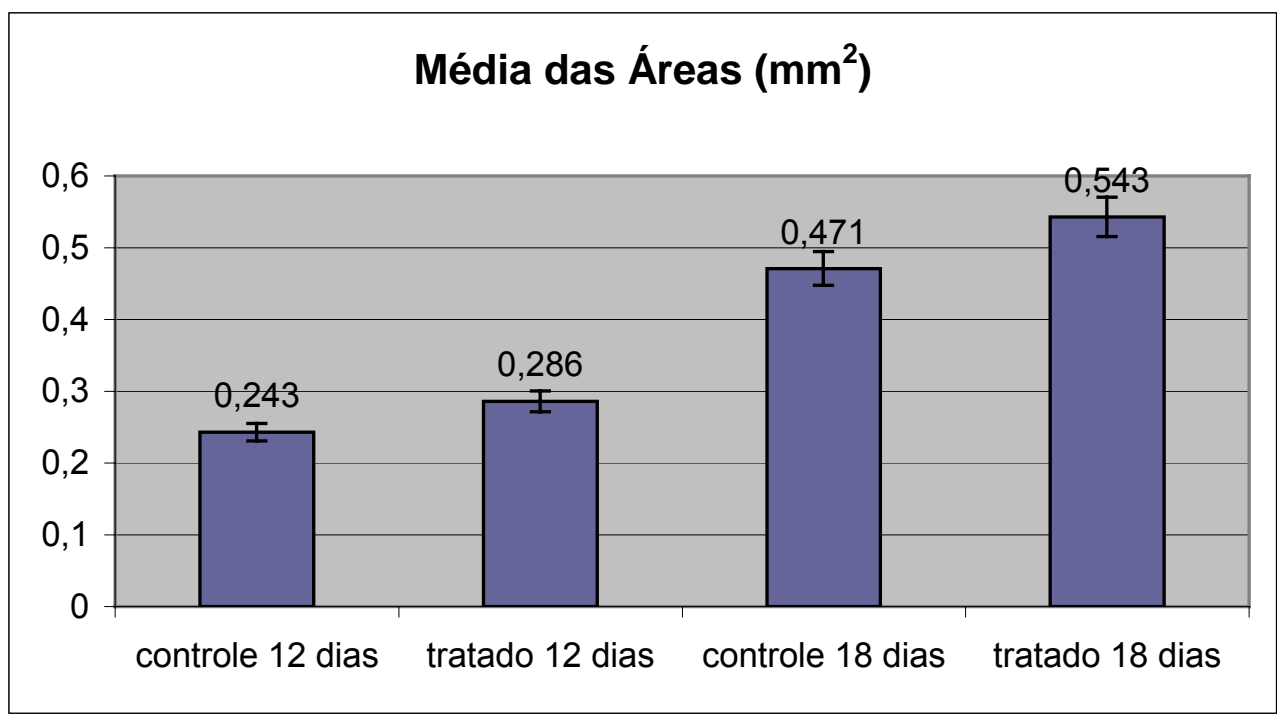

Figura 27 Média da área de osso formado no local da osteotomia para cada grupo

A Tabela 2 representa os valores das médias das áreas de osso formado e os respectivos desvios padrão calculados.

Tabela 2. Valores médios e desvio padrão das áreas de osso formado no local da osteotomia dos grupos controle e tratado.

\begin{tabular}{ccccc}
\hline & Controle 12 dias & Tratado 12 dias & Controle 18 dias & Tratado 18 dias \\
\hline Área $\left(\mathrm{mm}^{2}\right)$ & $0,243 ! 0,053$ & $0,286 ! 0,038$ & $0,471 ! 0,049$ & $0,543 ! 0,053$ \\
\hline
\end{tabular}

Os resultados não apresentaram diferença estatisticamente significante entre as médias das áreas calculadas quando relacionados os grupos controle 12 dias com o grupo tratado 12 dias. 
A relação entre os grupos controle 18 dias com tratado 18 dias bem como entre os grupos tratado 12 dias e tratado 18 dias das médias das áreas de osso formado apresentaram diferenças estatisticamente significantes.

Esses resultados sugerem que o tempo de tratamento para todos os grupos estudados neste trabalho não é o suficiente para que o tecido ósseo seja remodelado completamente, porém mostram que o tratamento com campo elétrico, tanto nos grupos de 12 dias quanto nos grupos de 18 dias, acelerou o processo de reparo ósseo quando são comparados os grupos controle e tratado. 


\section{DISCUSSÃO}

A estimulação elétrica utilizada para a promoção da osteogênese tem uma longa história, datada de 1812, quando corrente direta foi utilizada para consolidar uma fratura (BOYER, 1816). Apesar dessa tecnologia ter apresentado grande sucesso, desapareceu do meio de pesquisa por volta do século XIX, porque reivindicações com relação à sua eficácia não foram esclarecidas.

$\mathrm{Na}$ década de 80 , com o avanço dos estudos in vitro, utilizaram-se células ósseas em cultura a fim de estabelecer um mecanismo de interação entre campos elétricos e estas células. Esses estudos determinaram e esclareceram a dependência dos efeitos celulares observados com a intensidade e a freqüência de campos elétricos aplicados (SILVA, 1995).

Dentre vários estudos destaca-se o tratamento clássico de Maxwell para células em suspensão, onde a aplicação de campos elétricos de 10 a $60 \mathrm{~V} / \mathrm{cm}$ resulta em variações de potencial de membrana ou deslocamento iônico na superfície da membrana celular, cujos efeitos poderiam ser ativação direta de proteínas da membrana celular e variações de fluxos iônicos, atuantes como segundo mensageiros. Nesta fase de estudos também ficou bem determinado que o sítio de interação de campos elétricos aplicados externamente seria a membrana plasmática, que atua como sensor na recepção dos estímulos externos (SILVA, 1995).

Os parâmetros de campo elétrico aplicados devem ser tais que não ocorra a polarização da membrana celular. As variações do potencial elétrico da membrana podem atuar sobre o mecanismo de sinalização intracelular, provocando a liberação de $\mathrm{Ca}^{2+}$ dos armazéns internos; dessa forma o campo elétrico deve ser alternado em 
intervalos de freqüência determinado pelas propriedades dielétricas da membrana celular. Entre 1 e $10 \mathrm{MHz}$ não ocorre a polarização da membrana plasmática (SILVA, 1995).

Os fenômenos bioquímicos que são ativados nas células ósseas com a aplicação de campo elétrico continuam sendo especulados em cultura de células (BRIGTON et al., 2001) e permitem maior compreensão dos resultados obtidos quando campo elétrico é aplicado externamente para a remodelação de uma fratura.

Estudos como os de Friedenberg et al. (1971, 1974); Lavine et al. (1971) são exemplos de experimentos in vivo onde utilizaram-se estimulação elétrica em animais, que demonstraram a promoção da osteogênese eletricamente estimulada.

No presente estudo, o ensaio biomecânico de três pontos demonstrou que houve diferença significativa entre as médias das tensões dos grupos tratado 18 e 12 dias, sendo esta maior para o grupo tratado 18 dias. Os resultados referentes a esta propriedade, que trata-se do módulo de ruptura ou resistência ao dobramento do corpo de prova durante o ensaio de flexão, permite concluirmos que o tratamento com campo elétrico e o maior período de aplicação auxiliou na velocidade do processo de síntese de matriz orgânica que confere ao osso propriedades de tensão (ALBERTS, 1989) e início do processo de mineralização.

Resultados positivos também foram descritos por Hamanishi et al. (1995) realizando processos de alongamento ósseo em tíbia de coelhos. Utilizando corrente elétrica pulsada, as regiões estimuladas tiveram maior densidade mineral óssea quando comparadas com as do grupo controle, esses resultados indicam um efeito estimulador na mineralização ocorrida no osso alongado e possibilita a diminuição do tempo necessário para a retirada do prolongador. 
De acordo com SZEJNFELD (2000) no processo de formação óssea a mineralização consiste a fase final. Após a síntese de matriz orgânica, que liga osso novo ao osso velho, a deposição mineral inicia-se na interface entre o novo osteóide depositado e o osso calcificado e segue em direção à superfície óssea, calcificando completamente a nova unidade de osso.

Sendo assim, de acordo com os resultados supracitados, as amostras dos grupos do presente trabalho podem não apresentar formação óssea completa, estando no processo de deposição de matriz orgânica e início da mineralização, já os resultados descritos por Hamanishi et al. (1995) sugerem que o tecido ósseo esteja na fase final do processo de remodelamento, ou seja, a mineralização.

Uma das propriedades mecânicas analisadas neste trabalho que complementa os resultados supracitados é a medida da deformação do osso, chamada de flecha, correspondente a posição de flexão máxima, que foi menor para os grupos tratado $12 \mathrm{e}$ 18 dias quando comparadas às dos grupos controle 12 e 18 dias. Estes resultados podem ser conseqüência de os grupos estarem em diferentes fases do reparo ósseo. Einhorn (1996) descreve em seu trabalho que o calo ósseo que ainda não alcançou o remodelamento completo tem um comportamento mais elástico, o que lhe confere maior poder de deformação sem que ocorra o rompimento.

Wiesmann et al. (2001) observaram que osteoblastos em cultura são sensíveis a estímulos elétricos, que resultam no aumento do processo de mineralização in vitro. Essas observações podem justificar os resultados obtidos para tensão e flecha neste estudo pelo curto período de estimulação.

Os valores para o desvio padrão do momento de inércia demonstram maior dispersão dos resultados para todos os grupos estudados quando comparados aos 
respectivos valores das demais propriedades mecânicas, o que dificulta a comparação de outros tratamentos.

Por outro lado os valores de desvio padrão da linha neutra e do momento fletor não foram altos, o que demonstra menor dispersão dos valores encontrados para esta propriedade mecânica.

A posição do osso durante o ensaio é um ponto de observação fundamental, pois influencia na sua resistência a flexão, cada forma e cada posição equivalem a um momento de inércia diferente, alterando também a linha neutra e o momento fletor.

Neste estudo todas as tíbias foram igualmente posicionadas, mas, como afirmam Jämsä et al. (1998) a forma curva e cônica da tíbia de ratos pode interferir em testes biomecânicos.

Os valores encontrados para carga máxima não acompanham os valores da tensão de ruptura, isto sugere que apesar do grupo tratado não ter suportado uma carga maior que o grupo controle, o primeiro pode ter alcançado uma fase mais avançada do reparo ósseo, enquanto que o segundo ainda se encontra em uma fase mais precoce.

$\mathrm{Na}$ análise morfométrica as médias da área de osso formado foi significantemente maior para os grupos tratado quando comparadas com os respectivos grupos controle, bem como a média da área de osso formado foi maior para o grupo tratado 18 dias do que para o grupo tratado 12 dias.

Os resultados obtidos na análise morfométrica indicam que o tempo de tratamento com campo elétrico pulsado é fundamental para que o tecido ósseo alcance uma fase mais avançada de reparo. 
Com isso, é certo que o tratamento com campo elétrico pulsado auxilie no processo de reparo ósseo. 


\section{CONCLUSÃO}

Os resultados das análises biomecânica e morfométrica dos grupos tratados demonstraram maior formação de tecido ósseo na região da osteotomia experimental, quando comparados com os grupos controles, ainda, pôde-se observar um aumento na rigidez do tecido neo formado nas amostras dos grupos tratados.

Com isso conclui-se, neste trabalho, que o tratamento com campo elétrico acelerou o processo de reparo ósseo. 


\section{REFERÊNCIAS BIBLIOGRÁFICAS}

ADEY, W.R. (1986). The Sequence and energetics of cell membrane transductive coupling to intracelhilar enzyme systems. Bioelectrochemistry, Basel, v.15, n.3, p.447-456, June.

ALBERTS, B. et al. (1989). Differentiated cells and the maintenance of tissues. In: Molecular biology of the cel. $2^{\text {nd }}$ ed. New York: Garland. p.989-990.

ALLEN, F.D. et al. (1994). The Intracelhilar calcium response of osteoblast-like cells to $60 \mathrm{kHz}$ electric field stimulation from $10 \mathrm{~V} / \mathrm{m}$ to $1 \mathrm{kV} / \mathrm{m}$. In: ANNUAL MEETING OF THE SOCIETY FOR PHYSICAL REGULATION IN BIOLOGY AND MEDICINE, 14., 1994, Arlington. Proceedings... Frederick: SPRBM. p.1.

ARONSON, J.; SHEN, X. (1994). Experimental healing of distraction osteogenesis comparing metaphyseal with diaphyseal sites. Clinical Orthopaedic and Related Research, Philadelphia, v.301, p.25-30, Apr.

BASSETT, C.A.L.; PAWLUK, R.J.; PILLA, A.A. (1974). The Acceleration of fracture repair by eletromagnetic fields: a surgically non-invasive method. Annals of the New York Academy of Sciences, New York, v.238, p.242-262, Oct.

BERG, H.; ZHANG, L. (1993). Electrostimulation in cell biology by low-frequency electromagnetic fields. Electromagnetic Biology and Medicine, Boca Raton, v.12, n.2, p.147-163.

BRIGHTON, C.T. et al. (1985). Fracture healing in the habbit fibula when subjected to various capacitively coupled electrical fields. Journal of Orthopaedic Research, New York, v.3, n.3, p.331-340.

. (1995). Tibial nonunion treated with direct current, capacitive coupling, or bone graft. Clinical Orthopaedics and Related Research, Philadelphia, v.321, p.223-234, Dec.

. (2001). Signal transductionin electrically stimulated bone cells. The Journal of Bone and Joint Surgery, London, v.83.n.10, p.1514-1523, Oct.

BYRD, H.S.; SPICER, T.E.; CIERNEY, G. (1985). Management of open tibial fractures. Plastic and Reconstructive Surgery, Baltimore, v.76, p.719-730, Nov.

CHANG, M.C. et al. (1999). Treatment of large skeletal defects in the lower extremities using double-strut, free vascularized fibular bone grafting. Orthopedics, Thorofore, v.22, n.8, p.739-744, Aug.

CRENSHAW, A.H. (1992). General principles of fracture treatment. In: (Ed.). Campbell's operative orthopaedics. Saint Louis: Mosby-Year Book. 
DOBLARÉ, M.; GARCÍA, J.M.; GÓMEZ, M.J. (2004). Modelling bone tissue fracture and healing: a review. Engineering Fracture Mechanics, New York, v.71, n.13/14, p.1809-1840, Sept.

EINHORN, T.A. (1994). Bone metabolism and metabolic bone disease. In: FRYMOYER, F.W. Ortophaedic knowledge update 4 home sudy sillabus. Rodemont: American Academy of Orthopaedic Surgeons. p.69-88.

. (1998). The Cell and molecular biology of fracture healing. Clinical Orthopaedic and Related Research, Philadelphia, v.355, p.7-21, Oct. Supplement.

FOSTER, K.R.; SCHWAN, H.P. (1989). Dielectric properties of tissues and biological materials: a critical review. Critical Reviews in Biomedical Engineering, New York, v.17, n.1, p.25-104.

FRANKEL, V.H.; BURSTEIN, A.H. (1971). Orthopaedic biomechanics: the aplication of engineering to the muculoskeletal system. Philadelphia: Lea \& Febiger.

FRIEDENBERG, Z.B. et al. (1971). Stimulation of fracture healing by direct current in the rabbit fibula. Journal of Bone and Joint Surgery, London, v.53A, n.7, p.14001408 , Oct.

. (1974). The Response of non-tranmatized bone to direct current. Journal of Bone and Joint Surgery, London, v.56A, n.5, p.1023-1030, July.

FROST, H. (1991). A New direction for osteoporosis research: a review and proposal. Bone, Elmsford, v.12, n.6, p.429-437.

FROST, H.M. (1989). The Biology of fracture healing: an overview for clinicians - part I. Clinical Orthopaedic and Related Research, Philadelphia, v.248, p.283-293, Nov.

FUKADA, E.; YASUDA, I. (1957). On The piezoelectric effect of bone. Journal of the Physical Society of Japan, Tokyo, v.12, n.10, p.1158-1162, Oct.

GINEBRA, M.P.; PLANELL, J.A.; PARICIO, C. (2000). Structure and mechanical properties of cortical bone. In: ELICES, M. (Ed.). Structural biological materials. New York: Pergamon. Cap.3, p.33-71.

GOULD III, J.A. (1993). Biomecânica básica na terapia esportiva e ortopédica. In: . (Ed.). Fisioterapia na ortopedia e na medicina do esporte. Tradução de Alfredo Jorge Cherem. São Paulo: Manole. p.3-83.

GREENBAUM, M.A.; KANAT, I.O. (1993). Current concepts in bone healing: review of the literature. Journal of the American Podiatric Medical Association, Bethesda, v.83, n.3, p.123-129, Mar. 
GRODZINSKY, A.J. (1983). Electromechanical and physicochemical properties of connective tissue. Critical Reviews in Biomedical Engineering, New York, v.9, n.2, p.133-199.

GUARNIERO, R. (1987). Estudo da consolidação de fraturas na desnutrição protéica: trabalho experimental em ratos. Tese (Doutorado) - Faculdade de Medidina, Universidade de São Paulo, São Paulo, 1987.

HAVERSIAN SYSTEM. (2006). Disponível em:<http://www.cartage.org.Ib/en/themes/Sciences/Zoology/AboutZoology/Glossary/H/h aversiansystem.htm>. Acesso em:13 Jan. 2006.

HUANG, A.J. et al. (2004). Health plans' coverage determinations for technology-based interventions: the case of electrical bone growth stimulation. The American Journal of Managed Care, Plainsboro, v.10, n.12, p.957-962, Dec.

HULMES, D.J. (1992). The Collagen superfamily - diverses structures and assemblies. Essays in Biochemistry, London, v.27, p.49-67.

INOUE, O. et al. (2002). Effect of pulsed electromagnetic fields (PEMF) on late-phase osteotomy gap healing in a canine tibial model. Journal of Orthopaedic Research, New York, v.20, n.5, p.1106-1114, Sept.

ISHIDOU, Y. et al. (1994). Transforming growth factor-b in osteogenesis by direct current stimulation. In: CONFERENCE OF THE INTERNATIONAL SOCIETY FOR FRACTURE REPAIR, 4., 1994, Kobe. Proceedings... London: International Society for Fracture Repair.

JACQUES-ARSĖNE d'ARSONVAL. (2003). Disponível em:<http://chem.ch.huji.ac.il/ eugeniik/history/arsonval.html>. $\quad$ Acesso em: 15 août.2005.

JÄMSÄ, T. et al. (1998). Comparison of three-point bending test and peripheral quantitative computed tomography analysis in the evaluation of the strengh of mouse femur and tibia. Bone, Elmsford, v.23, n.2, p.155-161, Aug.

KATO, T. (1998). Single local injection of recombinant fibroblast growth factor-2 stimulates healing of segmental bone defects in rabbits. Journal of Orthopaedic Research, New York, v.16, n.6, p.654-659, Nov.

KORENSTEIN, R. et al. (1984). Capacitative pulsed electric stimulation of bone cells. Induction of cyclic-AMP and DNA synthesis. Biochimica et Biophysica Acta: molecular cell research, Amsterdam, v.803, n.4, p.302-307, Apr.

LEVY, D.D. (1974). A Pulsed electrical stimulation technique for inducing bone growth. Annals of the New York Academy of Sciences, New York, v.238, p.478-489, Oct. 
LIND, M. (1998). Growth factor stimulation of bone healing: effects on osteoblasts, osteotomies, and implants fixation. Acta Orthopaedica Scandinavica, Cambridge, v.69, p.1-37, Oct. Supplement 283.

LIRANI, A. (2004). Estudo comparativo dos efeitos do ultra-som e do laser de baixa intensidade no reparo ósseo em tíbia de rato. Dissertação (Mestrado) Escola de Engenharia de São Carlos/ Faculdade de Medicina de Ribeirão Preto/ Instituto de Química de São Carlos, Universidade de São Paulo, São Carlos, 2004.

LORICH, D.G. et al. (1998). Biochemical pathway mediating the response of bone cells to capacitive coupling. Clinical Orthopaedics and Related Research, Philadelphia, v.350, p.246-256, May.

LUCCHINETTI, E. (2001). Composite models of bone properties. In: JEE, W. Bone mechanics handbook. Boca Raton: CRC Press. Cap.3, p.101-119.

MARINO, A.A. (1977). Electrical osteogenesis: analysis. Clinical Orthopaedics and Related Research, Philadelphia, v.123, p.280-282, Mar.IApr.

MARTIN, R.B. (1984). Porosity and speci.c surface of bone: critical reviews. Biomedical Engineering, New York, v.10, n.3, p.179-222.

MCLEOD, K.J.; PORRES, L.; DONAHUE, H.J. (1994). Electric field induced changes in calcium ion activity response in osteoblastic cells: Frequency and duration dependence. In: ANNUAL MEETING OF THE SOCIETY FOR PHYSICAL REGULATION IN BIOLOGY AND MEDICINE, 14., 1994, Washington. Proceedings... [S.I.:s.n]. p.4.

MICHALANY, J. (1980). Técnica histológica em anatomia patológica. São Paulo: E.P.U.

PEREDA CARDOSO, O. et al. (1996). Electrostimulación del callo óseo. Revista Cubana de Ortopedia y Traumatología, Ciudad de las Habana, v.9, n.1, p.1-5, enero/dic.

POLLACK, S.R. (1984). Bioelectrical properties of bone. The Orthopedic Clinics of North America, Philadelphia, v.15, n.1, p.3-14, Jan.

REICHEL, H. et al. (1998). Biomechanical and densitometric bone properties after callus distraction in sheep. Clinical Orthopaedic and Related Research, Philadelphia, v.357, p.237-246, Dec.

REILLY, D.T.; BURSTEIN, A.H. (1975). The Elastic and ultimate properties of compact bone tissue. Journal of Biomechanics, New York, v.8, n.6, p.393-405.

ROBEY, P.G.; TERMINE, J.D. (1992). Biochemical markers of metabolic bone disease. In: COE, F.L.; FAVUS, M.J. Disorders of bone and mineral metabolism. New York: Raven Press. p.244-263. 
ROBINSON, R.A.; ELLIOT, S.R. (1957). The Water content of bone. I. The mass of water, inorganic crystals, organic matrix, and "CO2 space"components in a unit volume of dog bone. Journal of Bone and Joint Surgery, Boston, v.39A, n.1, p.167-188, Jan.

SKERRY, T.M.; PEAD, M.J.; LANYON, L.E. (1991). Modulation of bone loss during disuse by pulsed electromagnetic fields. Journal of Orthopaedic Research, New York, v.9, n.4, p.600-608.

SLUKA, K.A. et al. (1999). Spinal blockade of opioid receptors prevents the analgesia produced by TENS in arthritic rats. Journal of Pharmacology and Experimental Therapeutics, Baltimore, v.289, n.2, p.840-846, May.

SPADARO, J.A. (1997). Mechanical and electrical interations in bone remodeling. Bioelectromagnetics, New York, v.18, n.3, p.193-202.

SZEJNFELD, V.L. (2000). Osteoporose: diagnóstico e tratamento. São Paulo: Sarvier.

TARVAINEN, R. et al. (1994). Effect of clodronate on fracture healing in denervated rats. Bone, Elmsford, v.15, n.6, p.701-705, Nov./Dec.

TESLA, N. (1898). High frequency oscillators for electro-therapeutic and other purposes. The Electrical Engineer, Milbourne, v.26, n.550, p.477.

TREHARNE, R.W. et al. (1979). Application of direct, pulsed and SGP - shaped currents to in vitro fetal rat tibiae. In: BRIGHTON, C.T.; BLACK, J.; POLLACK, S.R. Electrical properties of bone and cartilage. New York: Grune \& Stratton. Cap.2, p.169-180.

TRIPOD (2005). Disponível em:<http://members.tripod.com/themedpage/histo tc.htm>. Acesso em: 14 Nov. 2005.

ULETT, G.A.; HAN, J.; HAN, S. (1998). Electroacupuncture: mechanisms and clinical application. Biological Psychiatry, Amsterdam, v.44, n.2, p.129-1382.

URIST, M.R. (1994). The Search for and the discovery of bone morphogenetic protein (BMP). In: URIST, M.R.; OCONNOR, B.T.; BURWELL, R.G. (Ed.). Bone grafts, derivates and substitutes. Oxford: Butterworth Heinemann. p.315-361.

VALONE, T.F. (2005). Bioelectromagnetic healing, its history and rationale for its use. Disponível em:<http://integrityresinst.crosswinds.net/BEMsHealing.html>. Acesso em: 20 Apr. 2005.

WEINER, S.; WAGNER, H.D. (1998). The Material bone: structure-mechanical function relations. Annual Review of Materials Science, Palo Alto, v.28, p.271-298, Aug. 
WIESMANN, H. et al. (2001). Electrical stimulation influences mineral formation of osteoblast-like cells in vitro. Biochimica et Biophysica Acta: molecular cell research, Amsterdam, v.1538, n.1, p.28-37, Feb.

YASUDA, I. (1977). Electrical callus and callus formation by electret. Clinical Orthopaedics and Related Research, Philadelphia, v.124, p.53-56, May.

YONEMORI, K. et al. (1996). Early effects of electrical stimulation on osteogenesis. Bone, Elmsford, v.19, n.2, p.173-180, Aug.

ZIZIC, T.M. et al. (1995). The Treatment of osteoarthritis of the knee with pulsed electrical stimulation. Journal of Rheumatology, Toronto, v.22, n.9, p.1757-1761. 


\section{APÊNDICES}

\section{APÊNDICE A - Dados Relativos ao Ensaio Biomecânico}

\begin{tabular}{|c|c|c|c|c|c|c|c|}
\hline $\begin{array}{l}\text { AMOSTRA } \\
\mathrm{T}-12 \text { DIAS }\end{array}$ & $\begin{array}{l}\text { CARGA MÁX } \\
\text { (KN) }\end{array}$ & $\begin{array}{c}\text { FLECHA } \\
\text { (MM) }\end{array}$ & $\begin{array}{l}\text { M. FLETOR } \\
\text { (N.MM) }\end{array}$ & $\begin{array}{l}\text { M. INÉRCIA } \\
\text { (MM4) }\end{array}$ & $\begin{array}{l}\text { L. NEUTRA } \\
\text { (MM) }\end{array}$ & $\begin{array}{l}\text { TENSÃO } \\
\text { (Mpa) }\end{array}$ & $\begin{array}{l}\text { ÁREA } \\
\text { (MM2) }\end{array}$ \\
\hline 1 & 0,06848 & 1,0300 & 0,2472128 & 37,7467 & 4,5935 & 0,03008401 & 13,9656 \\
\hline 2 & 0,06223 & 0,8600 & 0,2246503 & 26,6959 & 4,6638 & 0,03924663 & 13,8033 \\
\hline 3 & 0,04929 & 0,7500 & 0,1779369 & 7,5509 & 4,2372 & 0,09984959 & 8,7133 \\
\hline 4 & 0,07503 & 1,0600 & 0,2708583 & 43,099 & 6,0041 & 0,03773313 & 16,7557 \\
\hline 8 & 0,06099 & 0,5400 & 0,2201739 & 33,7461 & 6,3009 & 0,04110975 & 15,4402 \\
\hline 9 & 0,05976 & 1,5700 & 0,2157336 & 39,9634 & 6,0681 & 0,0327573 & 18,647 \\
\hline MÉDIAS & 0,05944714 & 1,04000000 & 0,21460419 & 26,97171429 & 4,55251429 & 0,04011149 & 12,47501429 \\
\hline DESV P & 0,37255872 & 0,37255872 & 0,04175000 & 16,81062825 & 2,17178220 & 0,02983177 & 6,31100452 \\
\hline
\end{tabular}

\begin{tabular}{|c|c|c|c|c|c|c|c|}
\hline $\begin{array}{l}\text { AMOSTRA } \\
\text { C - } 12 \text { DIAS }\end{array}$ & $\begin{array}{c}\text { CARGA MÁX } \\
\text { (KN) }\end{array}$ & $\begin{array}{c}\text { FLECHA } \\
\text { (MM) }\end{array}$ & $\begin{array}{l}\text { M. FLETOR } \\
\text { (N.MM) }\end{array}$ & $\begin{array}{l}\text { M. INÉRCIA } \\
\text { (MM4) }\end{array}$ & $\begin{array}{l}\text { L. NEUTRA } \\
\text { (MM) }\end{array}$ & $\begin{array}{c}\text { TENSÃO } \\
\text { (MPa) }\end{array}$ & $\begin{array}{l}\text { ÁREA } \\
\text { (MM2) }\end{array}$ \\
\hline 1 & 0,0714 & 1,4500 & 0,257833 & 6,1066 & 2,3341 & 0,09855 & 6,4473 \\
\hline 2 & 0,0738 & 1,3400 & 0,266499 & 7,0171 & 2,1134 & 0,080264 & 7,2671 \\
\hline 3 & 0,0761 & 1,0580 & 0,274805 & 7,7276 & 2,1602 & 0,07682 & 7,1911 \\
\hline 4 & 0,0533 & 1,0290 & 0,192472 & 8,8074 & 2,4462 & 0,053458 & 7,9398 \\
\hline 5 & 0,0635 & 0,8250 & 0,229305 & 13,0565 & 2,6497 & 0,046535 & 9,85 \\
\hline 6 & 0,0612 & 1,4880 & 0,220999 & 14,4083 & 2,58 & 0,039573 & 9,8602 \\
\hline 7 & 0,0507 & 0,8689 & 0,183083 & 13,5581 & 2,87 & 0,038755 & 7,6975 \\
\hline 8 & 0,0500 & 1,0250 & 0,180555 & 12,4651 & 2,4838 & 0,035977 & 9,0659 \\
\hline MÉDIAS & 0,06250000 & 1,13548750 & 0,22569388 & 10,39333750 & 2,45467500 & 0,05874150 & 8,16486250 \\
\hline ESV & 0,01051991 & 0,25691336 & 0,03798846 & 3,31483100 & 0,25209934 & 0,02341183 & 1,28168521 \\
\hline
\end{tabular}




\begin{tabular}{|c|c|c|c|c|c|c|c|}
\hline $\begin{array}{l}\text { AMOSTRA } \\
T-18 \text { DIAS }\end{array}$ & $\begin{array}{l}\text { CARGA MÁX } \\
\text { (KN) }\end{array}$ & $\begin{array}{l}\text { FLECHA } \\
\text { (MM) }\end{array}$ & $\begin{array}{l}\text { M. FLETOR } \\
\text { (N.MM) }\end{array}$ & $\begin{array}{l}\text { M. INÉRCIA } \\
\text { (MM4) }\end{array}$ & $\begin{array}{l}\text { L. NEUTRA } \\
\text { (MM) }\end{array}$ & $\begin{array}{l}\text { TENSÃO } \\
\text { (Mpa) }\end{array}$ & $\begin{array}{l}\text { ÁREA } \\
\text { (MM2) }\end{array}$ \\
\hline 15 & 0,01909 & 0,6200 & 0,0689149 & 82,9005 & 5,71 & 0,0047467 & 32,5377 \\
\hline 16 & 0,09399 & 0,5900 & 0,3393039 & 20,5076 & 4,765 & 0,07883824 & 14,0742 \\
\hline 17 & 0,07412 & 0,9900 & 0,2675732 & 21,9755 & 5,3669 & 0,06534726 & 13,0114 \\
\hline 18 & 0,07825 & 0,4900 & 0,2824825 & 23,6198 & 5,8368 & 0,06980558 & 15,5204 \\
\hline 19 & 0,03549 & 1,7700 & 0,1281189 & 13,6953 & 5,3548 & 0,05009391 & 11,0703 \\
\hline 17.1 & 0,03642 & 0,6747 & 0,1314762 & 1,0517 & 2,6224 & 0,32783416 & 3,1277 \\
\hline 18.1 & 0,04702 & 0,6791 & 0,1697422 & 1,7364 & 2,0178 & 0,19725052 & 3,1826 \\
\hline 19.1 & 0,04103 & 0,6366 & 0,1481183 & 0,7642 & 0,9957 & 0,19298795 & 3,0817 \\
\hline 20 & 0,05713 & 1,0154 & 0,2062393 & 1,1207 & 1,0879 & 0,20020321 & 3,7647 \\
\hline MÉDIAS & 0,05361556 & 0,82952222 & 0,19355216 & 18,59685556 & 3,75081111 & 0,13190084 & 11,0411888 \\
\hline DESV P & 0,02420710 & 0,39451944 & 0,08738763 & 26,01635820 & 2,04209590 & 0,10308897 & 9,59118435 \\
\hline
\end{tabular}

\begin{tabular}{cccccccc}
$\begin{array}{c}\text { AMOSTRA } \\
\text { C- 18 DIAS }\end{array}$ & $\begin{array}{c}\text { CARGA MÁX } \\
\text { (KN) }\end{array}$ & $\begin{array}{c}\text { FLECHA } \\
\mathbf{( M M )}\end{array}$ & $\begin{array}{c}\text { M. FLETOR } \\
\text { (N.MM) }\end{array}$ & $\begin{array}{c}\text { M. INÉRCIA } \\
\text { (MM4) }\end{array}$ & $\begin{array}{c}\text { L. NEUTRA } \\
\text { (MM) }\end{array}$ & $\begin{array}{c}\text { TENSÃo } \\
\text { (Mpa) }\end{array}$ & $\begin{array}{c}\text { ÁREA } \\
\text { (MM2) }\end{array}$ \\
\hline 1 & 0,06405 & 1,5734 & 0,2312205 & 4,8296 & 2,594 & 0,12418958 & 6,7677 \\
3 & 0,04302 & 0,9144 & 0,1553022 & 4,38 & 2,6839 & 0,09516337 & 7,1219 \\
4 & 0,04401 & 0,9600 & 0,1588761 & 5,0322 & 1,8167 & 0,05735667 & 6,1097 \\
5 & 0,05413 & 1,3067 & 0,1954093 & 3,9284 & 3,2986 & 0,16408134 & 4,2015 \\
6 & 0,04912 & 1,0041 & 0,1773232 & 4,9154 & 3,2857 & 0,11853172 & 5,6609 \\
7 & 0,0621 & 0,8875 & 0,224181 & 15,3759 & 4,436 & 0,06467699 & 8,9505 \\
8 & 0,0500 & 1,2350 & 0,180500 & 6,5126 & 3,3636 & 0,09322387 & 5,7196 \\
9 & 0,05531 & 0,7508 & 0,1996691 & 3,6445 & 2,3206 & 0,12713736 & 4,6771 \\
MÉDIAS & $\mathbf{0 , 0 5 5 3 4 1 1 1}$ & $\mathbf{1 , 0 9 5 0 7 7 7 8}$ & $\mathbf{0 , 1 9 9 7 8 1 4 1}$ & $\mathbf{6 , 3 6 1 2 4 4 4 4}$ & $\mathbf{3 , 0 8 0 7 8 8 8 9}$ & $\mathbf{0 , 1 0 7 7 4 9 1 2}$ & $\mathbf{6 , 3 2 0 2 5 5 5 6}$ \\
DESV P & $\mathbf{0 , 0 1 0 6 7 1 0 0}$ & $\mathbf{0 , 2 5 7 5 1 3 8 1}$ & $\mathbf{0 , 0 3 8 5 2 2 3 1}$ & $\mathbf{3 , 7 0 5 9 6 6 5 0}$ & $\mathbf{0 , 8 1 3 4 8 5 4 2}$ & $\mathbf{0 , 0 3 3 5 6 0 8 7}$ & $\mathbf{1 , 4 8 4 1 2 3 5 6}$
\end{tabular}




\section{APÊNDICE B - Dados Referentes a Análise Estatística _ teste t bilateral}

TABELA 1. Teste das Propriedades Mecânicas dos Grupos Tratado e Controle 18 dias.

\section{PROPRIEDADES}

CARGA

FLECHA

M. FLETOR

M. INÉRCIA

LINHA N.

TENSÃO

ÁREA

$\mathbf{t}$
0,21076
1,61
0,211
$-3,298$
$-0,911$
$-0,745$
$-2,46$

$-2,46$ t crítico

2,13145

2,13145

2,13145

2,13145

2,13145

2,13145

2,13145
ERRO PADRÃO

0,008187

0,16484

0,02954

3,71

0,7352

0,03242

1,9179
RESULTADO

NÃO REJEITO $\mathrm{H}_{0}$ NÃO REJEITO $\mathrm{H}_{0}$ NÃO REJEITO $\mathrm{H}_{0}$ REJEITO $\mathrm{H}_{0}$ NÃO REJEITO $\mathrm{H}_{0}$ NÃO REJEITO $\mathrm{H}_{0}$ REJEITO $\mathrm{H}_{0}$

TABELA 2. Teste das Propriedades Mecânicas dos Grupos Tratado e Controle 12 dias.

$\begin{array}{ccc}\text { PROPRIEDADES } & \mathbf{t} & \mathbf{t}_{\text {crítico }} \\ \text { CARGA } & 0,577 & 2,17881 \\ \text { FLECHA } & 0,589 & 2,17881 \\ \text { M. FLETOR } & 0,581 & 2,17881 \\ \text { M. INÉRCIA } & -3,4987 & 2,17881 \\ \text { LINHA N. } & -6,29982 & 2,17881 \\ \text { TENSÃO } & 1,3966 & 2,17881 \\ \text { ÁREA } & -3,3304 & 2,17881\end{array}$

$\begin{array}{cc}\text { ERRO PADRÃO } & \text { RESULTADO } \\ 0,0052907 & \text { NÃO REJEITO Ho } \\ 0,1619732 & \text { NÃO REJEITO H } \\ 0,019104 & \text { NÃO REJEITO Ho } \\ 4,7385 & \text { REJEITO H } \\ 0,333 & \text { REJEITO H } \\ 0,01334 & \text { NÃO REJEITO H } \\ 1,2942 & \text { REJEITO H }\end{array}$

TABELA 3. Teste das Propriedades Mecânicas dos Grupos Tratado 12 dias e 18 dias.

$\begin{array}{ccc}\text { PROPRIEDADES } & \mathbf{t} & \mathbf{t}_{\text {crítico }} \\ \text { CARGA } & -0,61303 & 2,17881 \\ \text { FLECHA } & -1,0027 & 2,17881 \\ \text { M. FLETOR } & -0,612 & 2,17881 \\ \text { M. INÉRCIA } & -1,3388 & 2,17881 \\ \text { LINHA N. } & -0,89296 & 2,17881 \\ \text { TENSÃO } & 2,221 & 2,17881 \\ \text { ÁREA } & -0,556 & 2,17881\end{array}$

ERRO PADRÃO
0,0095125
0,2099
0,03441
6,255
0,8978
0,04133
2,5782

RESULTADO NÃO REJEITO $\mathrm{H}_{0}$ NÃO REJEITO $\mathrm{H}_{0}$ NÃO REJEITO $\mathrm{H}_{0}$ NÃO REJEITO $\mathrm{H}_{0}$ NÃO REJEITO $\mathrm{H}_{0}$ REJEITO $\mathrm{H}_{0}$ NÃO REJEITO $\mathrm{H}_{0}$ 
TABELA 4. Teste das Áreas de osso formado entre os Grupos Tratado e Controle 12 dias.

\begin{tabular}{|c|c|c|c|c|}
\hline PROPRIEDADE & $\mathrm{t}$ & $\mathbf{t}_{\text {crítico }}$ & ERRO PADRÃO & RESULTADO \\
\hline Área & $-\mathbf{1 , 7 4}$ & $\mathbf{2 , 4 4 7}$ & $\mathbf{0 , 0 2 4 7 4}$ & Não Rejeito $\mathrm{H}_{\mathbf{0}}$ \\
\hline
\end{tabular}

TABELA 5. Teste das Áreas de osso formado entre os Grupos Tratado e Controle 18 dias.

\begin{tabular}{|c|c|c|c|c|}
\hline PROPRIEDADE & $\mathbf{t}$ & $\mathbf{t}_{\text {critico }}$ & ERRO PADRÃO & RESULTADO \\
\hline Área & $-2,63$ & 2,447 & 0,02735 & Rejeito $\mathrm{H}_{0}$ \\
\hline
\end{tabular}

TABELA 6. Teste das Áreas de osso formado entre os Grupos Tratado 12 dias e Tratado 18 dias.

\begin{tabular}{|c|c|c|c|c|}
\hline PROPRIEDADE & $\mathbf{t}$ & $\mathbf{t}_{\text {critico }}$ & ERRO PADRÃO & RESULTADO \\
\hline Área & $\mathbf{9 , 6 1 8}$ & $\mathbf{2 , 4 4 7}$ & $\mathbf{0 , 0 2 6 7 2}$ & $\mathbf{H}_{0}$ \\
\hline
\end{tabular}


APÊNDICE C - Dados Referentes a Análise Morfométrica

\begin{tabular}{|c|c|c|c|c|}
\cline { 2 - 5 } \multicolumn{1}{c|}{} & \multicolumn{4}{c|}{ Área $\left.\mathbf{( m m}^{\mathbf{2}}\right)$} \\
\hline Amostras & $\begin{array}{c}\text { Controle 12 } \\
\text { dias }\end{array}$ & Tratado 12 dias & $\begin{array}{c}\text { Controle 18 } \\
\text { dias }\end{array}$ & $\begin{array}{c}\text { Tratado 18 } \\
\text { dias }\end{array}$ \\
\hline 1 & 0,3 & 0,2 & 0,5 & 0,6 \\
\hline 2 & 0,2 & 0,3 & 0,4 & 0,5 \\
\hline 3 & 0,3 & 0,3 & 0,5 & 0,6 \\
\hline 4 & 0,2 & 0,3 & 0,5 & 0,6 \\
\hline 5 & 0,3 & 0,3 & 0,5 & 0,5 \\
\hline 6 & 0,2 & 0,3 & 0,4 & 0,5 \\
\hline 7 & 0,3 & 0,3 & 0,5 & 0,5 \\
\hline MÉDIAS & 0,243 & 0,286 & 0,471 & 0,543 \\
\hline DESV P & 0,053 & 0,038 & 0,049 & 0,053 \\
\hline
\end{tabular}

